NBER WORKING PAPER SERIES

SYSTEMATIC MANAGED FLOATING

Jeffrey A. Frankel

Working Paper 23663

http://www.nber.org/papers/w23663

\author{
NATIONAL BUREAU OF ECONOMIC RESEARCH \\ 1050 Massachusetts Avenue \\ Cambridge, MA 02138 \\ August 2017
}

This paper was written for the 4th Asian Monetary Policy Forum, Singapore, 26 May, 2017, organized under the auspices of the Asian Bureau of Finance and Economic Research (ABFER), with support from the University of Chicago Booth School of Business, the National University of Singapore Business School and the Monetary Authority of Singapore (MAS). The author would like to thank Shruti Lakhtakia and Tilahun Emiru for assiduous research assistance, Andrew Rose and Sebnem Kalemli-Ozcan for useful discussion, and Rose and Assaf Razin for discussant comments at the AMPF conference. Tables 2.1-2.4 draw on new joint research with Danxia Xie. Faults of the paper are the author's alone. The views expressed herein are those of the author and do not necessarily reflect the views of the National Bureau of Economic Research.

The author has disclosed a financial relationship of potential relevance for this research. Further information is available online at http://www.nber.org/papers/w23663.ack

NBER working papers are circulated for discussion and comment purposes. They have not been peer-reviewed or been subject to the review by the NBER Board of Directors that accompanies official NBER publications.

(C) 2017 by Jeffrey A. Frankel. All rights reserved. Short sections of text, not to exceed two paragraphs, may be quoted without explicit permission provided that full credit, including () notice, is given to the source. 
Systematic Managed Floating

Jeffrey A. Frankel

NBER Working Paper No. 23663

August 2017

JEL No. F31,F33,F41

\begin{abstract}
$\underline{\text { ABSTRACT }}$
A majority of countries neither freely float their currencies nor firmly peg. But most of the remainder in practice also don't obey such well-defined intermediate exchange rate regimes as target zones. This paper proposes to define an intermediate regime, to be called "systematic managed floating," as an arrangement where the central bank regularly responds to changes in total exchange market pressure by allowing some fraction to be reflected as a change in the exchange rate and the remaining fraction to be absorbed as a change in foreign exchange reserves. An operational criterion for judging systematic managed floaters is a high correlation between exchange rate changes and reserve changes. The paper rejects the view that exchange rate regimes make no difference. In regressions to test effects on real exchange rates, we find that positive external shocks tend to cause real appreciation for most systematic managed-floaters; more strongly so for pure floaters; and not at all for most firm peggers. Two measures of exogenous external shocks are used: (i) for commodity-exporters, a country-specific index of global prices of the export commodities and (ii) for other Asian emerging market economies, the VIX.
\end{abstract}

Jeffrey A. Frankel

Harvard Kennedy School

Harvard University

79 JFK Street

Cambridge, MA 02138

and NBER

jeffrey_frankel@harvard.edu

A Ppt, data appendix \& Turkey appendix is available at https://scholar.harvard.edu/frankel/publication-topics-new/exchange-rates-and-currencies-0 


\section{Systematic Managed Floating}

\section{Introduction}

According to textbook theory, when countries choose their exchange rate regime they are choosing the extent to which they will be able to run an independent monetary policy despite external shocks. On the one hand, a firmly fixed exchange rate gives up the ability to set an independent monetary policy, unless capital controls or other impediments are used to break the link between domestic and foreign interest rates. On the other hand, a free-floating exchange rate maximizes insulation of the domestic real economy: an adverse foreign shock causes a nominal and real depreciation of the domestic currency, which works to moderate what would otherwise be negative real effects on the domestic trade balance, output and employment. In response to a positive foreign shock, currency appreciation dampens its real effects as well.

There are also intermediate regimes that lie at various points along the spectrum between fixed and floating exchange rates. These intermediate regimes include managed floats, bands, basket pegs, crawls, and other arrangements. ${ }^{1}$ The argument for the intermediate regimes is that they allow an intermediate degree of monetary independence in return for an intermediate degree of exchange rate flexibility.

For concreteness, consider the history of emerging market economies (EMs) since the turn of the century. As an aggregate class they have, broadly speaking, experienced four periods of big alternating shifts in the external environment for their balance of payments. In the first period from 2003 to mid-2008, the external environment was positive, as US monetary policy was easy, commodity prices were rising, and international investors were not especially concerned about risk as they reached for any EM returns that were even a little higher than those on offer in the advanced countries. The second period was the Global Financial Crisis that began in mid-2008 and eased a year later. This was a negative shock for EM economies: risk perceptions leapt and commodity prices plummeted. The third period, in 2010-11, was essentially a repeat of the first, with a favorable financial environment and a recovery in commodity prices leading to substantial EM inflows. Fourth was the period that began with the Taper Tantrum of May 2013 and continued at least through the China Tantrum of the second half of 2015: the first stages of a reversal in US monetary policy and a new fall in commodity prices led to EM outflows.

\footnotetext{
${ }^{1}$ E.g., for Asia: Williamson (2001), Ito (2001), and Frankel (2003).
} 
Central banks in different Emerging Market countries responded differently to these external shocks. Figure 1 (adapted from Goldman Sachs) shows responses of Asian central banks to the positive shock of 2010. Reserve accumulation is on the vertical axis and currency appreciation on the horizontal axis. On the one hand, Korea and Singapore appear as relatively more-managed floaters, intervening in the foreign exchange market somewhat more and appreciating less. On the other hand, India, Malaysia, Thailand and the Philippines, took the positive shock mostly in the form of increases in the value of their currencies and not primarily as increased reserves.

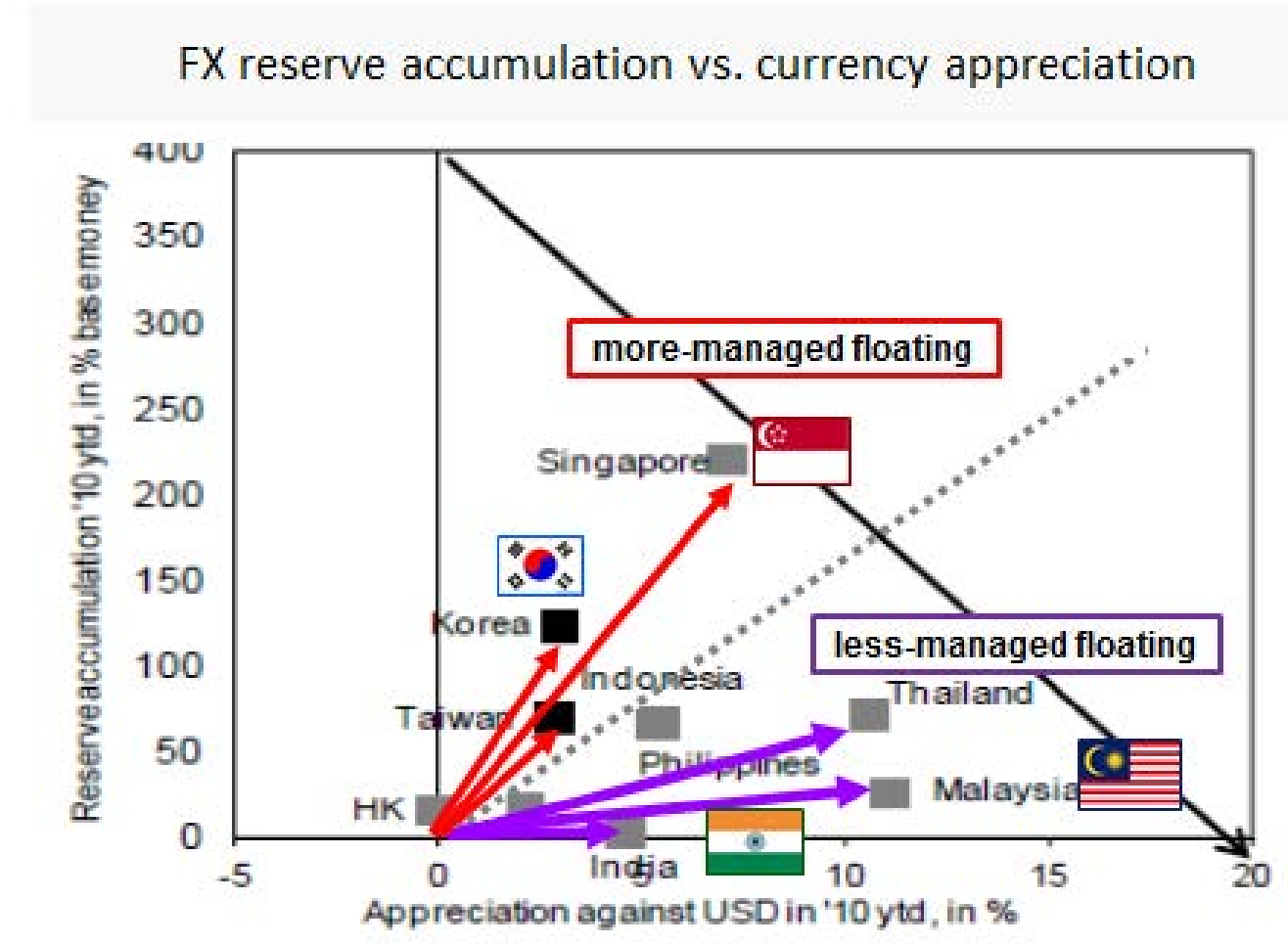

Source: Gs Global ECs Research, 1013/2010.

Data: Haver Analytics and Bloomberg

Figure 1: Reactions of Asian central banks to 2010 inflows

Figure 2 shows responses to the "taper tantrum" of May-August 2013, when Federal Reserve Chairman Ben Bernanke announced the intention to begin phasing down US quantitative easing by the end of the year, which produced an immediate rise in US interest rates and a reversal of EM capital flows. Again, Singapore mostly intervened while India and the Philippines mostly took the adverse shock as a change in the exchange rate, that is, a depreciation. 
FX reserve accumulation vs. currency appreciation

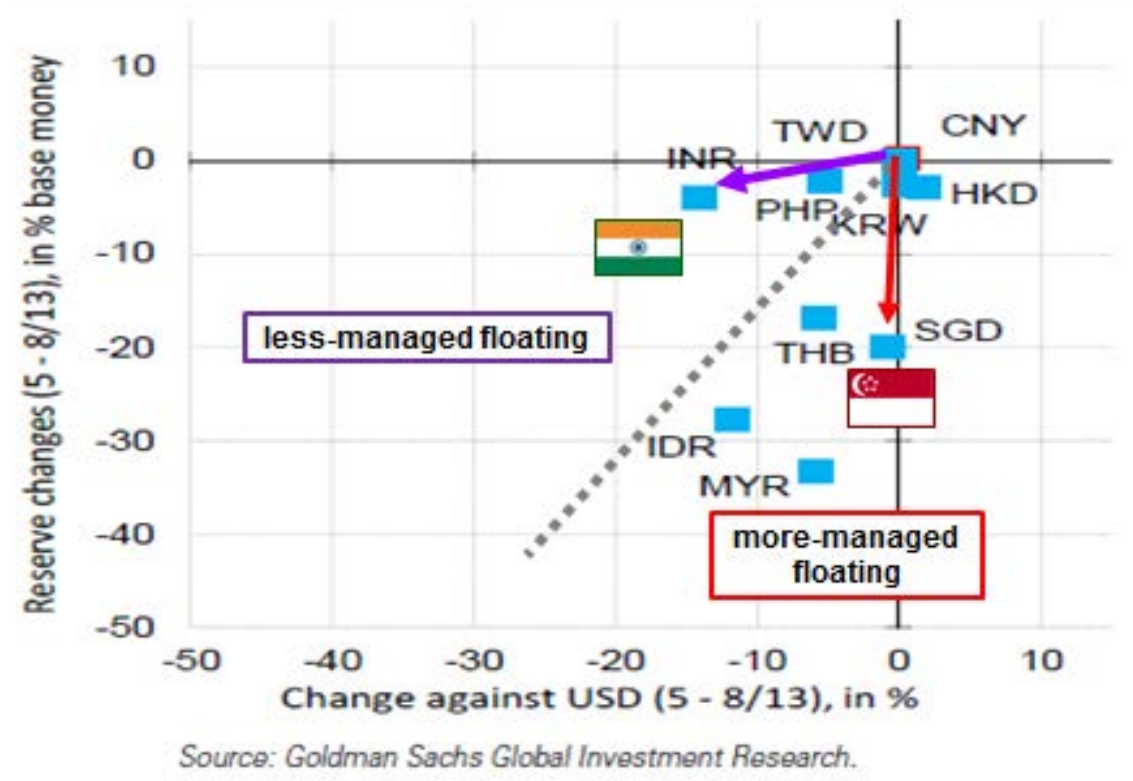

Figure 2: Reactions of central banks to outflows of May-Aug., 2013, taper tantrum

Finally, Figure 3 shows responses to the "China tantrum" of May-August 2013. Once again, Singapore intervened in the foreign exchange market, while the Philippines took the negative shock more in the form of a depreciation of its currency.

FX reserve accumulation vs. currency appreciation

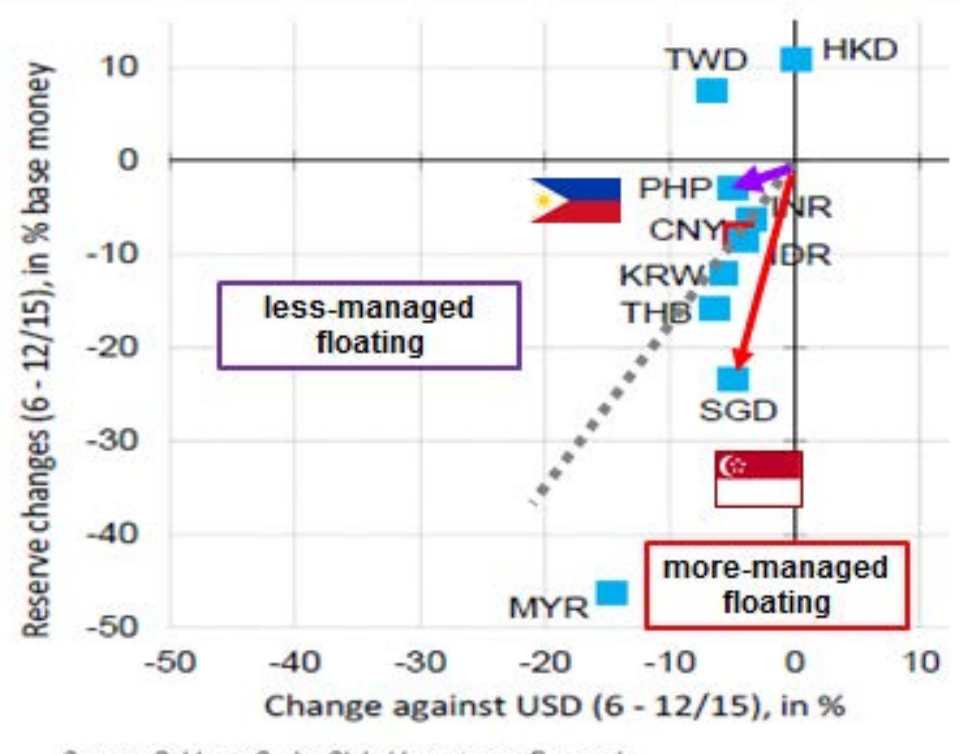

Source: Goidman Sachs Global Investment Research.

Figure 3: Reactions of central banks to outflows of May-Aug., 2013, taper tantrum 
These are just three episodes. But they illustrate how some countries choose to manage their floats more heavily and others less.

One supposes that the countries that allowed greater movements in their nominal exchange rates in response to these positive and negative external shocks also achieved greater movements in their real exchange rates and may have done so with the intention of mitigating the effects of the shocks on their balance of payments and real economies. Hong Kong in this sample is the one economy that is committed to intervening heavily enough to keep its exchange rate fixed against the dollar, and is willing to give up its monetary independence for the other advantages that this stability brings (reducing costs to international trade and investment and providing a credible anchor for monetary policy). So far, so consistent with the conventional textbook framework.

But the textbook framework has been challenged. The paper reviews the challenges in Part 1. Part 2 reviews some of the problems with identifying what exchange rate regime a country follows in practice and offers some evidence on a set of Asian and other currencies. Part 3 seeks to determine whether the regime makes a difference for the real exchange rate. The focus is on three regimes: firm fixing, free floating and, especially, systematically managed floating.

\section{Four challenges to the conventional wisdom}

The conventional wisdom about the role of regime choices has been assaulted from several directions. Many of the assaults fall under four rubrics: (a) "the corners hypothesis," (b) "dilemma vs. trilemma," (c) "intervention ineffectiveness" and (d) "exchange rate disconnect." We review these four challenges, as a prelude for defending the conventional view.

\section{a. The corners hypothesis}

Sometimes known as the vanishing intermediate regime, the corners hypothesis is the claim that in a modern world of high capital mobility, the intermediate regimes are no longer viable. Countries are forced to choose between free floating, on the one hand, and hard pegs on the other hand. Hard pegs are exchange rates that are firmly fixed through such institutions as currency boards, official dollarization or monetary union.

What are the origins of the corners hypothesis? A precursor is Friedman (1953, p.164): "In short, the system of occasional changes in temporarily rigid exchange rates seems to me the worst of two worlds: it provides neither the stability of expectations that a genuinely rigid and stable exchange rate could provide in a world of unrestricted trade...nor the continuous sensitivity of a flexible exchange rate." 
Such intermediate regimes as target zones or bands became popular in the 1980s. The earliest known reference rejecting them in favor of the firm-fixing and free-floating corners is by Eichengreen (1994). The context was not emerging markets, but rather the European exchange rate mechanism (ERM). In the ERM crisis of 1992-1993, Italy, the United Kingdom, and others were forced to devalue or drop out altogether, and the bands were subsequently widened substantially so that France could stay in. This crisis suggested to some that the strategy that had been planned previously - a gradual transition to the EMU, where the width of the target zone was narrowed in a few steps-might not be the best way to proceed after all. Crockett (1994) made the same point. Obstfeld and Rogoff (1995) concluded, "A careful examination of the genesis of speculative attacks suggests that even broad-band systems in the current EMS style pose difficulties, and that there is little, if any, comfortable middle ground between floating rates and the adoption by countries of a common currency." The lesson that "the best way to cross a chasm is in a single jump" was seemingly borne out subsequently, when the leap from wide bands to EMU proved successful in 1998-1999.

In the aftermath of the East Asia crises of 1997-1998, the hypothesis was applied to emerging markets and was rapidly adopted by the financial establishment as the new conventional wisdom. Four prominent examples were Council on Foreign Relations (1999), Fischer (2001), Summers (1999), and Meltzer (2000). ${ }^{2}$

But there never was a good theoretical rationale for the corners hypothesis and recent empirical results have re-asserted the viability of intermediate regimes.

On the theoretical side, nothing has changed the traditional logic that intermediate exchange rate regimes deliver an intermediate degree of insulation from foreign shocks in return for an intermediate degree of nominal exchange rate stability. One example of such an intermediate regime is the band, which was well-modeled in the target zone literature initiated by Krugman (1991). Another example is the adjustable peg, which can be modeled as an escape clause invoked in the event of a sufficiently big shock, as modeled by Obstfeld (1997).

Or consider a systematically managed float: If the central bank responds to potentially large inflows by intervening in the foreign exchange market to buy up half of the increased supply of foreign exchange, allowing the other half of the shock to show up as an increase in the value of its currency, then it gets half of the exchange rate stability and half of the impact of the shocks. (It is perhaps surprising that the systematic management has seldom been formalized. To operationalize "systematically managed floating," Part 2(b) of this paper identifies it simply by the condition that there is a high positive correlation between the change in foreign exchange reserves and the change in the foreign exchange value of the currency.) These are all counter-examples to the corners hypothesis.

${ }^{2}$ Ghosh, Ostry, and Qureshi (2015) offer a more recent empirical evaluation. 
Beyond the normative question as to whether intermediate regimes are advisable is the evidence from classification schemes on what countries are actually doing. A large and growing percentage of IMF members continue to choose managed floats and other intermediate regimes. ${ }^{3}$ To the author, it seems that the corners hypothesis is dead. ${ }^{4}$

\section{b. The challenge to the trilemma}

Traditional textbook theory says that floating exchange rates help insulate small countries against global financial factors such as foreign monetary conditions, each country choosing the monetary policy that suits its own economic conditions. "Dilemma, not trilemma" represents the claim that floating exchange rates do not in fact insulate countries from foreign shocks and that only capital controls can do that.

The textbook theory is part of the long-standing principle in international macroeconomics (often associated with Robert Mundell) that goes by the name of "the Impossible Trinity." Also called the "trilemma," the proposition states that even though a country might wish to have a fixed exchange rate, highly integrated financial markets, and the ability to set its own monetary policy, it cannot have all three of these things. The logic is simple. If there are no differences between the domestic currency and foreign currencies and no barriers to the cross-border movement of capital, then the domestic interest rate is tied to the world interest rate. The domestic country loses the ability to set its own interest rate.

One familiar graphical interpretation of the Impossible Trinity or Trilemma shows the three desirable characteristics as three sides of a triangle: exchange rate stability, financial market integration, and monetary independence. Now consider challenges (a) and (b). The corners hypothesis is the claim that financial integration forces a country to choose between the firmly-fixed vertex and the free-floating vertex, while the contrary position is that nothing stops a country from choosing an intermediate point anywhere along the side of the triangle. The "dilemma" view is very different: the triangle collapses into a single line segment, running

\footnotetext{
${ }^{3}$ E.g., Ghosh, Ostry, and Qureshi (2015). Their "managed float" category has grown to be the largest category of exchange rate regime, with the proviso: "'Managed floating', however, is a nebulous concept." (The proviso suggests the utility of defining a regime that we can call systematically managed floating.) The most recent classification scheme, by Ilzetzki, Reinhart, Rogoff (2017) again does not support a trend to the corners. The classification studies are discussed in Part 2 of the paper.

${ }^{4}$ The author conducted an unscientific poll of annual samples of IMF staff from 2000 to 2010. At the start, a substantial majority of participants reported the perception that a belief in the corners hypothesis was in effect IMF policy. Subsequently the percentage declined and eventually hit zero.
} 
from "monetary independence via capital controls" to "open capital markets," with the choice of exchange rate regime not relevant for monetary independence. ${ }^{5}$

This area of research is of particular interest in 2017, a time when the Fed is expected to continue to pursue a series of increases in US interest rates, which might lead international investors to pull funds out of emerging countries and trigger new crises as sometimes in the past.

Do floating rates in fact insulate countries from foreign interest rates as the traditional textbook view advertises? Rey (2014) has led a new wave of skepticism on this score. ${ }^{6}$ She finds that one global factor explains an important part of the variance of a large cross section of returns of risky assets around the world. This time-varying global factor can be interpreted as the perceived importance of risk, as reflected in a measure such as the VIX. US monetary policy is, in turn, a driver of this global factor and of international credit flows and leverage.

It is possible that transmission of liquidity and risk effects may invalidate the insulation proposition. Some say that the power to set independent monetary policy was compromised when interest rates hit the zero lower bound after 2008. After all, many countries with floating exchange rates suffered effects of the US-originated Global Financial Crisis. Farhi and Werning (2014) find theoretically that capital market imperfections may prevent floating rates from performing the shock absorption role claimed in traditional macroeconomic analysis and that in such circumstances taxation of capital flows can be welfare-improving.

To argue that floating rates do not automatically insulate against foreign disturbances is to take on a straw man, however. Given the importance of international capital flows and other transmission mechanisms, the claim in favor of floating is not that it automatically gives complete insulation even when domestic monetary policy remains passive. The claim is, rather, that it allows the freedom to respond to shocks so as to achieve the desired level of domestic demand. Indeed there is no shortage of empirical studies finding that floating does help countries retain an important degree of monetary autonomy. ${ }^{7}$

5 Complicating matters, some graphical interpretations depict capital controls, firm fixes, and floating as the three sides of the triangle instead of the three corners. In this case an intermediate regime, such as half-floating and half-independence, cannot be represented by identifying a point along the side of the triangle, but is instead described as "rounding the corners." (Klein and Shambaugh, 2015.)

${ }^{6}$ Also Miranda-Agrippino and Rey (2014), Devereux and Yetman (2014), Edwards (2015).

7 The studies include Aizenman, Chinn, and Ito (2010, 2011), Di Giovanni and Shambaugh (2008), Klein and Shambaugh (2012, 2015), Obstfeld (2015), Obstfeld, Shambaugh and Taylor 


\section{c. The challenge to intervention effectiveness}

Another challenge is the claim that foreign exchange intervention is powerless to affect nominal exchange rates (unless it is non-sterilized, in which case it is just another kind of monetary policy), let alone real exchange rates. This view was originally rooted in models in which the exchange rate was determined by the supply and demand for money; if intervention was sterilized so as to leave the money supply unchanged, then it had no effect. It was thought that non-monetary claims against the government did not have an effect on market interest rates and exchange rates. This was because among advanced countries (the only ones that floated at the time), financial markets were highly liquid, international capital flows unencumbered, default risk a non-issue, and government debt perhaps considered rendered irrelevant by Ricardian equivalence. Uncovered interest parity held because investors were able to arbitrage away international differences in expected returns. If a European or Japanese central bank bought dollar bonds, but then sold an equal number of domestic bonds so as to leave the monetary base unchanged, it was thought to have no effect. The ineffectiveness of sterilized intervention was accepted not just among most academics but also among many central bankers. ${ }^{8}$

There have long been good arguments on the other side of the debate, including theories that go back to portfolio balance models, as well as empirical results. ${ }^{9}$ Foreign exchange intervention could be effective regardless whether it changed the monetary base. ${ }^{10}$

Given experience since the 2008 global financial crisis, it is perhaps puzzling that sterilized intervention is still often presumed ineffective. Among advanced countries that experience includes: quantitative easing, where the composition of assets underlying a given monetary base is thought to make a difference; a surprising relapse to imperfect international integration of financial markets illustrated by a new failure of covered interest parity, let alone

(2005), Shambaugh (2004), and Frankel, Schmukler and Servén (2004). Han and Wei (2017) find that flexible exchange rates offer more autonomy when the center country raises interest rates than when it lowers rates.

8 E.g., Truman (2003).

${ }^{9}$ Some studies of the effectiveness of intervention by advanced-country central banks include Beine, Bénassy-Quéré, and Lecourt (2002), Dominguez (2006), Dominguez, Fatum, and Vacek (2013), Dominguez and Frankel (1993a,b), Fatum and Hutchison (2003, 2010), Humpage (1999) Ito (2003), Kearns and Rigobon (2005), and Obstfeld (1990). Surveys include Edison (1993), Menkhoff (2010), and Sarno and Taylor (2001).

10 I see the venerable "signaling hypothesis" (Mussa, 1981) as largely a red herring. Why would a central bank choose such an opaque way of signaling its intentions? What practical difference does it make whether or not sterilized intervention implies that money supplies will change some day, if it is in the distant future? 
uncovered interest parity; a reversal in the previous trend of diminishing home bias; and the unexpected loss of full creditworthiness represented by triple-A ratings by the US and some other major high-income (but high-debt) countries. More than just money matters.

In any case, if one considers the effectiveness of intervention and managed floating these days, one is usually looking at Emerging Markets, since far more of them are managed floaters than was the case before the turn of the century, when they targeted exchange rates, while the largest industrialized countries have recently ceased foreign exchange intervention altogether. ${ }^{11}$ Among Emerging Market countries the failure of interest parity and the impact of outstanding stocks of government debt are nothing new. Hence the notion that sterilized intervention can have effects comes more naturally in the case of EM economies.

Of the recent studies of foreign exchange intervention in EM currencies, most focus on just one or two countries. ${ }^{12}$ Fratzscher, Gloede, Menkhoff, Sarno, and Stöhr (2016) manages to marshal data from an impressive sample of 33 countries. Its conclusions are broadly similar to those regarding intervention by major central banks in an earlier era. First, intervention can be effective. Second it tends to be more effective when seeking to move the exchange rate in the direction of longer-term equilibrium. Third, operations are more likely to be effective when orally communicated.

\section{d. Exchange rate disconnect}

The fourth challenge to the conventional view is the "exchange rate disconnect," which says that the nominal exchange rate has no implications for real economic factors such as the real exchange rate, trade, or output. This covers a broad range of papers, from empirical studies to theoretical models. The empirical studies fail to find correlations between nominal exchange rates and real variables. ${ }^{13}$ The theoretical models (including Real Business Cycle models) have the property that shocks have the same effect on the real exchange rate regardless whether the currency floats, in which case the shock appears in the nominal exchange rate, or is fixed, in which case the same shock shows up in price levels instead. The strong claim in this case is that it doesn't matter whether foreign exchange intervention is sterilized or not, nor whether it affects the nominal exchange rate or not: the same real exchange rate emerges regardless.

\footnotetext{
${ }^{11}$ Frankel (2016) relates the G7's post-millennium renunciation of foreign exchange intervention.

12 Besides Fratzscher et al (2016), other recent studies of EM intervention include Adler, Lisack and Mano (2015), Adler and Tovar (2011), Blanchard, Adler, and de Carvalho Filho (2015), Daude, Levy-Yeyati and Nagengast (2014), Disyatat and Galati (2007) and the collection introduced by Mohanty (2013). Menkhoff (2013) surveys the earlier ones.

13 Including Devereux and Engel (2002), Flood and Rose (1999), and Rose (2011).
} 


\section{What countries actually do}

This section of the paper considers the exchange rate regimes that countries follow. Our empirical focus will ultimately fall on three: firm fixing, free floating, and systematicallymanaged floating.

\section{a. Classification systems}

i. De facto vs. de jure

It is well-established that de facto regimes need not correspond to de jure, that what a country does in practice often differs from what it says it does officially. To take three cases: countries that say they fix their exchange rate often in practice adjust it at the first serious sign of trouble ${ }^{14}$; countries that say they float often can't refrain from intervening in the market ${ }^{15}$; and countries that say they follow a basket peg often keep the weights secret so that they can depart from the basket without immediate detection. ${ }^{16}$ The rampant discrepancies have led to a collection of studies that attempt to estimate and report the true de facto regimes. ${ }^{17}$

The IMF discontinued reporting the regime claims of its members at face value and began to offer its own de facto schemes. ${ }^{18}$ It seems likely, however, that they are still heavily influenced by the claims of member governments, whereas academic researchers are more likely to go wherever the data lead them (which is not always the right way, it must be admitted).

\section{ii. Disagreement among de facto classification schemes}

It has become evident that the various de facto classification schemes, though designed to get at the "true answer," disagree widely among themselves. ${ }^{19}$ A table in Frankel (2004)

\footnotetext{
14 Obstfeld and Rogoff (1995) and Klein and Marion (1997).

15 The famous "fear of floating": Calvo and Reinhart (2002) and Reinhart (2000).

${ }^{16}$ E.g., Frankel, Fajnzylber, Schmukler and Servén (2001).

17 Some or the prominent de facto classification schemes are Ghosh, Gulde, and Wolf (2000), Ilzetzki, Reinhart and Rogoff (2017), Reinhart and Rogoff (2004), Bénassy-Quéré, Coeuré, and Mignon (2004), and Levy-Yeyati and Sturzenegger (2001, 2003, 2005). Surveys of the literature on classification of exchange rate regimes include Klein and Shambaugh (2012), Rose (2011), and Tavlas, Dellas and Stockman (2008).

18 Bubula and Ötker-Robe (2002).

${ }^{19}$ E.g., Eichengreen and Razo-Garcia (2013).
} 
showed that the classifications of three prominent schemes coincided with the IMF de jure classification only $50.4 \%$ of the time, averaging across the three. But they coincided with each other even less, only $38.6 \%$ of the time! ${ }^{20}$ Similarly, a table in Bénassy-Quéré, et al (2004) showed three de facto schemes on average correlated .69 with the IMF de jure scheme, but only .63 with each other. A table in Shambaugh (2007) reported for three de facto schemes an average of 80 percent agreement with the de jure listings, but only 78 per cent among themselves. Finally, a table in Klein and Shambaugh (2011) showed that three de facto schemes coincided with the IMF classification 62 per cent of the time, and coincided with each other also 62 per cent of the time. All-in-all, the evidence is clear that the evidence of the classification schemes is not clear. ${ }^{21}$

\section{iii. Reasons for disagreement}

There are three reasons why the classification schemes give such different answers: differences in estimation techniques or other methodology; murkiness of true regimes; and frequent changes.

1. Differences in methodology. Some schemes work off of the official classifications, reclassifying countries when necessary. ${ }^{22}$ Other approaches estimate de facto regimes from observed data alone. Among the latter, some look simply at the volatility of the exchange rate, without comparing it to the variability of reserves. ${ }^{23}$ Admittedly, if the variance of the currency vis-à-vis the dollar or other major currency is essentially zero, that is clear evidence of a fixed exchange rate. But it does not follow that the flexibility of exchange rate regimes can be ranked according to the variability of the exchange rate. One should compare the variance of the exchange rate changes to the variance of reserve changes. Only if the latter is large relative to the former can the regime be pronounced highly flexible. Otherwise a large exchange rate variance might in truth be due to large external shocks. Conversely an exchange rate may show relatively low variability, but this might be due to small shocks rather than a heavily managed exchange rate. That is the proper inference if foreign exchange reserves are even more stable

\footnotetext{
${ }^{20}$ Correlation of the flexibility rankings of the regimes shows an average of .40 between the three de facto schemes and the IMF de jure scheme, but a correlation of only .88 among the three themselves.

${ }^{21}$ In all four studies, one of the de facto classification schemes considered is Levy-Yeyati and Sturzenegger (2001). In Frankel (2004) the other two are Reinhart and Rogoff (2004) and Ghosh, Gulde and Wolf (2000). In Bénassy-Quéré et al (2004) the other two are their own and Bubula and Ötker-Robe (2002). In Shambaugh (2007) and Klein and Shambaugh (2011) they are his own and Reinhart and Rogoff (2004).

${ }^{22}$ Tavlas, Dellas and Stockman (2008).

${ }^{23}$ Shambaugh (2004) and Ilzetzki, Reinhart and Rogoff (2017).
} 
or if there is direct evidence of little or no foreign exchange intervention. To take the example of Figure 1, the Singapore dollar appreciated more in 2010 than the Indian rupee, but this was apparently because it experienced a bigger shock (measured by total exchange market pressure), perhaps because it is a smaller more open economy, and not because its regime has higher flexibility.

Reinhart (2000) and Calvo and Reinhart (2002) compared exchange rate variability with reserve variability to show how de facto exchange rate regimes differed from de jure characterizations. The classification scheme of Levy-Yeyati and Sturzenegger $(2001,2003)$ is entirely based on a comparison of the variance of exchange rate changes versus the variance of reserve changes.

2. Murky regimes. Relatively few countries follow a single clean regime. Reinhart and Rogoff (2004), for example, argue that there should be a category of free-falling currencies and point out that it is misleading to characterize them as floating merely because the changes are so large. Rose (2011) more generally calls many countries' regimes neither fixed nor floating, but "flaky."

3. Changeability. For many countries, if they do follow a peg or other clear regime, it is often not for very long. They tend every few years to change parameters (devaluing, widening a band, changing weights in a basket, etc.) or to switch regimes altogether. One can cope with frequent changes by estimating equations for short sub-periods or using the Bai-Perron econometric technique which allows for endogenous estimation of structural breaks. A country that follows no systematic regime for longer than a year or two at a time should perhaps be treated as having no systematic regime at all, joining those in the murky category.

\section{b. Identifying countries that are systematic managed floaters}

Within the large set of countries that are neither firm fixers nor free floaters, we would like to try to identify the subset that systematically manage their floats. We are not interested in the murky regimes. We have no particular hypothesis in their case. By contrast, in the last part of the paper we have a hypothesis that we want to test for the managed floaters: that they experience external shocks as accommodating movements in their real exchange rate, to a greater extent than the firm fixers do, but to a lesser extent than the free floaters.

How do we identify the systematic managed floaters? We take as a starting point those that are identified as managed floaters by the IMF or by one of the other classification schemes such as Ilzetzki, Reinhart and Rogoff (2017). But we have something more specific in mind, represented by the word "systematic." We mean that when faced with Exchange Market 
Pressure, they tend generally to take a particular portion of it in the form of currency appreciation and the remainder in the form of higher foreign exchange reserves, where the portion lies somewhere between all (which would be free floating) and nothing (which would be firm fixing).

One way to approach the problem is to run a regression of changes in the exchange rate against Exchange Market Pressure. A coefficient that is significantly greater than zero and significantly less than one indicates a systematic managed float. We elaborate below, with updated estimates of the regimes followed by a number of Asian countries.

A second way to approach the problem is to treat reserve changes rather than exchange rate changes as the dependent variable. One estimates a central bank reaction function by running a regression of foreign exchange intervention against the exchange rate. A significant coefficient implies that the country is a systematic managed floater. We do that for the case of Turkey (with a focus on two alternative measures of intervention) in the section that follows the next.

But there is a problem. Why should intervention be considered the dependent variable and the exchange rate the independent variable? Or why, on the other hand, should the exchange rate be considered the independent variable? In truth, aren't they both endogenous in the case of a managed float? We also offer a new, third, approach, which makes no presumption as to causality.

\section{i. A simple-minded criterion for systematic managed floaters}

We here propose an amazingly simple-minded test to identify systematic managed floaters. Whether its crudeness is considered a vice or its elegance is considered a virtue, it at least has the desirable property of making no presumption about direction of causality.

The test is to compute for each country the correlation of the change in the foreign exchange value of the currency (in percent) with the change in reserves (as a percentage of the monetary base). If the correlation is positive and high enough to clear some threshold, it is judged a systematic managed floater. At one extreme, a truly fixed exchange rate will show a correlation of zero, because the exchange rate by definition never changes. At the other extreme, a purely floating exchange rate will again show a coefficient of zero, because reserves by definition never change. But it is not just the residents of fixed and floating corners that will fail to meet this criterion. Most countries that are normally classified as intermediate regimes 
will fail the criterion as well, their intervention being much more episodic than that. Only those that respond to exchange market pressure systematically will show a high positive correlation. ${ }^{24}$

A correlation coefficient of 1 , hypothetically, would mean that the management of the float is perfectly systematic. A separate question is how aggressive the management is. Assume a constant of proportionality $\phi$ between percentage exchange rate changes and percentage reserve changes:

$$
\Delta s=\phi(\Delta \operatorname{Res}) / M B,
$$

where $\Delta s \equiv$ the change in the log of the foreign exchange value of the domestic currency; $\triangle$ Res $\equiv$ the change in the central bank's holdings of foreign exchange reserves; $\mathrm{MB} \equiv$ monetary base; and $\phi \equiv$ the parameter that captures how flexible is the exchange rate regime.

At one extreme, if the constant $\phi$ is zero then the regime in the limit is so heavily managed that it once again collapses into a peg. At the far extreme, as the constant goes to infinity, the currency is so lightly managed that in the limit becomes a float. In between, a finite $\phi$ implies an intermediate degree of management, which is what we have in mind. But, again, the question whether the intervention is systematic (high correlation coefficient) is independent of the question whether the intervention is aggressive (low $\phi$ ).

There is one dimension on which the correlation test may lose its claim to elegance. That is the question of what is the numeraire currency in which the exchange rate and value of foreign exchange reserves is measured. We start by using the dollar, which will give the right answer for many countries. But some countries gauge the value of their currency in terms of other major countries or a weighted average of trading partners. This obviously needs to be considered for those that formally declare a role for a basket in their regime, but it is likely true at an implicit level of others too.

We can address this problem with alternative approaches such as using the SDR as the numeraire or experimenting on a case-by-case basis. A well-specified way to estimate the implicit weights in a currency basket is described in the following section. For the moment we will be content with the dollar numeraire.

Table 1 reports the coefficient of correlation between the percentage change in the foreign exchange value of the domestic currency and the change in foreign exchange reserves, scaled by the monetary base. The countries with the highest correlation, strongly suggesting

${ }^{24}$ We compute the correlation on changes rather than levels, in part to avoid non-stationarity. One property of working with first differences is that the criterion will not be impaired by a long-term trend in reserves, if the central bank seeks to build them up, nor by a long-term trend in the exchange rate. (Such a trend is to be expected under a crawling peg - the " $\mathrm{C}$ " in $\mathrm{BBC}$ or Band-Basket-Crawl). 
systematic management of their floating currencies, are Singapore, Korea and India. Others that are also above a threshold of 0.25 , and which are thereby also judged to have systematically managed floats, are Malaysia, Philippines, Thailand, Turkey, South Africa, Peru and Russia. As expected, countries known to have firm pegs have coefficients well below the threshold, close to or equal to zero: Hong Kong, Kuwait, Saudi Arabia, Bahrain, Qatar, the United Arab Emirates, and Brunei. Also below the threshold are countries that are thought to float freely: Australia, Canada, Chile, and New Zealand. In Part 3 of the paper we see whether these categories make a difference for insulation from external shocks.

$\begin{array}{lc}\text { Table 1: Correlation between } \Delta \mathrm{s} \text { and }(\boldsymbol{\Delta} \text { Res)/MB } & \text { (Jan. 1997-Dec.2015) } \\ \text { Asian Economies (Non-Commodity-Exporters) } \\ \text { Hong Kong } & 0.0446 \\ \text { India } & 0.4453 \\ \text { Korea, Rep. } & 0.5530 \\ \text { Malaysia } & 0.2685 \\ \text { Philippines } & 0.3023 \\ \text { Singapore } & 0.6074 \\ \text { Thailand } & 0.2643 \\ \text { Turkey } & 0.2950 \\ \text { Vietnam } & 0.1142\end{array}$

\section{Commodity Exporters}

$\begin{array}{ll}\text { Australia } & 0.1755 \\ \text { New Zealand } & 0.2199 \\ \text { South Africa } & 0.2736 \\ \text { Brazil } & 0.2884 \\ \text { Chile } & 0.1007 \\ \text { Colombia } & 0.2100 \\ \text { Indonesia } & -0.0061 \\ \text { Peru } & 0.2758 \\ \text { Papua New Guinea } & 0.2396 \\ \text { Mongolia } & 0.1889 \\ \text { Canada } & 0.1021 \\ \text { Kazakhstan } & 0.1506 \\ \text { Kuwait } & -0.1025 \\ \text { Russia } & 0.2637 \\ \text { Saudi Arabia } & -0.0319 \\ \text { Bahrain } & 0 \\ \text { Qatar } & 0 \\ \text { UAE } & 0.0437 \\ \text { Brunei } & 0.0465\end{array}$

Note: $s$ is the log of the exchange rate defined as the dollar price of the domestic currency. 
ii. Estimates of de facto exchange rate regimes for some Asian countries

Frankel and Wei (1994) ran regressions to estimate weights on the dollar, yen and other major currencies in the implicit baskets guiding the exchange rates of smaller Asian countries. At a time when many saw the yen as becoming increasingly important in East Asia, the finding was that the dollar was still by far the dominant currency in most cases. ${ }^{25}$ The exercise is a rare case in which, under the null hypothesis of a true basket peg, the estimation should produce, not just statistically significant coefficients, but an $\mathrm{R}^{2}$ close to 1.0. But few countries in Asia or elsewhere claim to peg to a basket and fewer still actually follow through de facto. At most, a regression of the local currency value against other major currencies tells us the weights in a loose anchor around which the exchange rate is allowed to vary.

Frankel and Wei (2008) synthesized (i) the weight-estimation methodology with (ii) a technique to estimate the degree of systematic intervention to dampen fluctuations relative to the basket. This was achieved by adding Exchange Market Pressure (EMP) as another righthand side variable along with the values of the major foreign currency. The change in Exchange Market Pressure is defined as the percentage increase in the foreign exchange value of the currency plus the increase in foreign exchange reserves (over some denominator such as the monetary base). ${ }^{26}$ If $\beta$, the coefficient on $E M P$, is estimated to be close to zero, the regime is a peg (to the basket, whatever its component or components may be). If $\beta$ is estimated to be close to 1 , it is a pure float. For most countries, it is in between, suggesting an intermediate exchange rate regime.

$$
\Delta \log H_{t}=c+\sum_{j=1}^{k}\left(w_{j} \Delta \log X_{j, t}\right)+\beta \Delta E M P_{t}+u_{t}
$$

where $H$ is the value of the home currency $i$ (measured in terms of a numeraire unit, in this case the $\mathrm{SDR}) ; \quad X_{j}$ is the value of the dollar, euro, yen, or other foreign currencies $j$ that are candidates for components of the basket, measured in terms of the same numeraire; and $\triangle E M P_{t}$ is Exchange Market

25 Among other similar papers estimating weights were Bénassy-Quéré (1999) and BénassyQuéré, Coeuré, and Mignon (2004). Ogawa (2006) and Frankel and Wei (2009) are among those who applied the technique to discern China's exchange rate policy when it moved away from a dollar peg after 2005. More recently, China's yuan has itself joined the list of candidate units in the regression to determine the regimes followed by other Asian countries. E.g., Subramanian (2011a, 2011b) claims a rising share for the yuan.

${ }^{26}$ Exchange Market Pressure was originally introduced by Girton and Roper (1977). Here we impose the a priori constraint that a one percentage increase in the foreign exchange value of the currency and a one percentage increase in the supply of the currency (the change in reserves as a share of the monetary base) have equal weights, whereas Girton and Roper and others have normalized by standard deviations. 
Pressure $\equiv \Delta \log H_{t}+(\Delta R e s) / M B_{t}$. The flexibility parameter in equation (2) is directly related to the lexibility parameter in equation (1):

$$
\beta=\phi /(1+\phi)
$$

Frankel and Xie (2010) further refined the Frankel-Wei methodology by adapting the econometric technique of Bai and Perron (2003) to allow endogenous estimation of structural break points, so that parameters could change. Appendix Tables 2 and 3 apply the technique to weekly data from the period 1999-2009 for India and Thailand, which have been candidates for a basket-basket-crawl (BBC) at some parts of their recent history. The equations are estimated in rate of change form, to eliminate non-stationarity. Both for Thailand and for India the estimate for $\beta$, the coefficient on EMP, was significant greater than zero but significantly less than 1 , suggesting systematic managed floating. For Thailand, the weight on the dollar moved in the range .6 to .8 , with the remaining weight falling on the euro and yen. For India, the weight on the dollar went as high as .9 in the early 2000 s.

Even though we label them "systematic," it is noteworthy that there are several structural breaks in the parameters. For Thailand the flexibility parameter $\beta$ is significantly greater than zero and less than 1 for all four time sub-periods within 1999-2009, suggesting relatively consistent behavior. For India, the same is true of the parameter in four out of six sub-periods, but it is insignificantly different from zero in two out of six.

Similar estimates from the period 1999-2009 for seven other Asian currencies are reported in an on-line Appendix, with structural breaks again identified by the week. Singapore, the Philippines, and South Korea show managed floats throughout the period. The technique shows China starting to qualify as a managed float in 2006. For Malaysia we cannot reject free floating in 1999 or fixing in 2000-05 and 2008-09, but the ringgit shows a managed float in between. For Indonesia we cannot reject free floating in 2001-02, but the rupiah shows managed floating thereafter. Turkey shows variable behavior during 1999-2000 but managed floating starts in 2001.

Next we update the estimates to 2017, for four of the Asian currencies that are of most interest. Again, the technique allows estimation of the weights in the implicit basket that the authorities treat as the anchor or reference rate (as in Frankel and Wei, 1994), while also estimating the parameter that calibrates the degree of exchange rate flexibility relative to that basket (as in Frankel and Wei, 2008) and estimating endogenously possible structural breaks in any of these parameters (as in Frankel and Xie, 2010). The data set runs from 1999 to 2017. The exchange rate observations are daily, which requires interpolation of the components of monthly reserve data to compute the EMP variable. 
The updated results are shown in Tables 2.1-2.4. All four currencies qualify for systematic managed floats, if one overlooks the many small structural breaks in the parameters. (We use a .01 significance level for defining a structural break.) For Singapore the flexibility parameter appears higher during March 2013 - February 2017 than it did before, above .7. For Korea, the estimated flexibility parameter has risen over time, from 0.7 to 0.9 . For India, the flexibility parameter appears higher during November 2008 - February 2017 than earlier, well above .9.

For China the managed float starts in July 2005. In recent years the estimated weight on the dollar has declined from 0.9 to 0.5 . The flexibility parameter appears quite high during the period August 2010-April 2017: above 0.9. One might suspect that this is a sign of asymmetric response by the Chinese authorities to recent outflows and depreciation, as compared to the earlier period of inflows and appreciation. But in fact the parameter changes on the post-2014 downside do not particularly run in that direction. The value of the RMB in terms of dollars peaked in January 2014. Since that date, net capital outflows have mostly been pushing in the opposite direction from the preceding 10 years. Holdings of foreign exchange reserves by the People's Bank of China peaked in June 2014, at $\$ 4.0$ trillion, and went down by almost a trillion dollars subsequently.

Singapore's basket has allotted a significant weight to China's RMB during the period since January 2008, at the expense of the US dollar. The heavy weight on the euro and the smaller weight on the yen both remain undiminished.

The Korean won also has put significant weight on the RMB since August 2005. There is no sign of RMB influence for India, where the weights have been roughly steady: 0.5 on the dollar, 0.3 on the euro, and weights of 0.1 on both the Japanese yen and the British pound. 
Tables 2: Estimation of Implicit Weights and Flexibility Parameter, for Four Asian Currencies, updated to 2017. ${ }^{27}$

\subsection{China: RMB's Exchange Rate Regime}

Before the exchange rate reform of July 21, 2005,

Daily M1:1999-M6:2005

\begin{tabular}{lc}
\multicolumn{2}{c}{ Daily M1:1999-M6:2005 } \\
\hline & $(1)$ \\
VARIABLES & $1 / 1 / 1999-7 / 20 / 2005$ \\
\hline & \\
US \$ & $0.999 * * *$ \\
& $(0.000)$ \\
Euro $€$ & -0.000 \\
& $(0.000)$ \\
Jpn Y & 0.000 \\
& $(0.000)$ \\
$\Delta$ EMP & 0.001 \\
& $(0.001)$ \\
Constant & -0.000 \\
& $(0.000)$ \\
Observations & \\
R & 1,634 \\
GB $€$ & 1.000 \\
\hline
\end{tabular}

$* * * p<0.01, * * p<0.05, * p<0.1$. (Robust standard errors in parentheses.)

27 Thanks to Danxia Xie. The methodology is from Frankel and Wei (2008), but allowing for endogenously estimated structural breaks as in Frankel and Xie (2010). 
Identifying Break Points in Renminbi Regime

Daily M7:2005-M4:2017

\begin{tabular}{lcccc}
\hline \multirow{2}{*}{ VARIABLES } & $(2)$ & $(3)$ & $(4)$ & $(5)$ \\
& $7 / 22 / 2005-$ & $6 / 6 / 2007-$ & $8 / 11 / 2008-$ & $8 / 25 / 2010-$ \\
& $6 / 5 / 2007$ & $8 / 8 / 2008$ & $8 / 24 / 2010$ & $11 / 4 / 2011$ \\
\hline \multirow{2}{*}{ US $\$$} & & & & \\
& $0.896^{* * *}$ & $0.692^{* * *}$ & $0.864^{* * *}$ & $0.449^{* * *}$ \\
Euro $€$ & $(0.013)$ & $(0.025)$ & $(0.025)$ & $(0.014)$ \\
& $0.057^{* * *}$ & $0.192^{* * *}$ & $0.091^{* * *}$ & $0.343^{* * *}$ \\
JPY & $(0.013)$ & $(0.025)$ & $(0.014)$ & $(0.009)$ \\
& $0.028^{* * *}$ & $0.057^{* * *}$ & $0.024^{* * *}$ & $0.120^{* * *}$ \\
& $(0.007)$ & $(0.008)$ & $(0.005)$ & $(0.006)$ \\
& $0.161^{* * *}$ & $0.454^{* * *}$ & $0.216^{* * *}$ & $0.915^{* * *}$ \\
Constant & $(0.022)$ & $(0.039)$ & $(0.043)$ & $(0.021)$ \\
& $-0.000^{* * *}$ & $-0.000^{* * *}$ & $-0.000^{* * *}$ & $-0.001^{* * *}$ \\
& $(0.000)$ & $(0.000)$ & $(0.000)$ & $(0.000)$ \\
Observation & & & & \\
$R^{2}$ & 467 & 296 & 512 & 301 \\
GB£ & 0.986 & 0.968 & 0.996 & 0.994 \\
\hline
\end{tabular}

\begin{tabular}{lccc}
\hline & $(6)$ & $(7)$ & $(8)$ \\
VARIABLES & $11 / 7 / 2011-1 / 9 / 2013$ & $1 / 10 / 2013-2 / 3 / 2015$ & $2 / 4 / 2015-4 / 28 / 2017$ \\
\hline \multirow{4}{*}{ US\$ } & & & \\
& $0.461^{* * *}$ & $0.490^{* * *}$ & $0.500^{* * *}$ \\
Euro $€$ & $(0.011)$ & $(0.009)$ & $(0.005)$ \\
& $0.331^{* * *}$ & $0.327^{* * *}$ & $0.319^{* * *}$ \\
JPY & $(0.007)$ & $(0.007)$ & $(0.005)$ \\
& $0.098^{* * *}$ & $0.073^{* * *}$ & $0.075^{* * *}$ \\
& $(0.004)$ & $(0.003)$ & $(0.003)$ \\
EMMP & $0.935^{* * *}$ & $0.904^{* * *}$ & $0.931^{* * *}$ \\
& $(0.016)$ & $(0.014)$ & $(0.010)$ \\
Constant & $-0.000^{* * *}$ & $-0.000^{* * *}$ & $0.000^{* * *}$ \\
& $(0.000)$ & $(0.000)$ & $(0.000)$ \\
& & & \\
Observations & 294 & 517 & 559 \\
$\mathrm{R}^{2}$ & 0.996 & 0.994 & 0.997 \\
GB£ & 0.110 & 0.109 & 0.106 \\
\hline
\end{tabular}

${ }^{* * *} p<0.01, * * p<0.05, * p<0.1$. (Robust standard errors in parentheses.)

$\Delta \mathrm{EMP} \equiv \Delta \log H_{t}+(\Delta R e s) / M B_{t}$ (daily interpolation). 


\subsection{India: Identifying Break Points in India's Exchange Rate Regime}

Daily M8:2005-M2:2017

\begin{tabular}{lcccc}
\hline & $(1)$ & $(2)$ & $(3)$ & $(4)$ \\
VARIABLES & $8 / 2 / 2005-$ & $9 / 5 / 2007-$ & $11 / 3 / 2008-$ & $8 / 8 / 2011-$ \\
& $9 / 4 / 2007$ & $10 / 31 / 2008$ & $8 / 5 / 2011$ & $10 / 1 / 2013$ \\
\hline US $\$$ & $0.450^{* * *}$ & $0.673^{* * *}$ & $0.456^{* * *}$ & $0.436^{* * *}$ \\
& $(0.096)$ & $(0.097)$ & $(0.041)$ & $(0.023)$ \\
Euro $€$ & $0.298^{* * *}$ & $0.217^{* * *}$ & $0.357^{* * *}$ & $0.361^{* * *}$ \\
& $(0.026)$ & $(0.039)$ & $(0.011)$ & $(0.005)$ \\
Jpn Y & $0.065^{* * *}$ & 0.030 & $0.116^{* * *}$ & $0.095^{* * *}$ \\
& $(0.019)$ & $(0.023)$ & $(0.007)$ & $(0.004)$ \\
Cn Y & 0.096 & -0.019 & -0.006 & 0.000 \\
& $(0.100)$ & $(0.092)$ & $(0.041)$ & $(0.023)$ \\
$\Delta$ EMP & $0.768 * * *$ & $0.639 * * *$ & $0.935^{* * *}$ & $0.992^{* * *}$ \\
& $(0.032)$ & $(0.046)$ & $(0.013)$ & $(0.003)$ \\
Constant & $-0.001^{* * *}$ & $-0.001 * * *$ & $-0.000^{* * *}$ & $0.000^{* * *}$ \\
& $(0.000)$ & $(0.000)$ & $(0.000)$ & $(0.000)$ \\
Observations & 523 & 292 & 692 & 540 \\
$\mathrm{R}^{2}$ & 0.911 & 0.910 & 0.980 & 0.996 \\
GB£ & 0.091 & 0.100 & 0.078 & 0.108 \\
\hline
\end{tabular}

\begin{tabular}{lcc}
\hline & $(5)$ & $(6)$ \\
VARIABLES & $10 / 2 / 2013-$ & $5 / 11 / 2015-$ \\
& $5 / 8 / 2015$ & $2 / 28 / 2017$ \\
\hline US\$ & $0.431^{* * *}$ & $0.487^{* * *}$ \\
Euro $€$ & $(0.032)$ & $(0.009)$ \\
& $0.356^{* * *}$ & $0.331^{* * *}$ \\
Jpn Y & $(0.010)$ & $(0.004)$ \\
& $0.065^{* * *}$ & $0.080^{* * *}$ \\
Cn Y & $(0.009)$ & $(0.003)$ \\
& 0.027 & -0.009 \\
$\Delta E M P$ & $(0.031)$ & $(0.011)$ \\
& $0.963^{* * *}$ & $0.981 * * *$ \\
Constant & $(0.010)$ & $(0.007)$ \\
& $-0.001^{* * *}$ & $-0.000 * * *$ \\
Observations & $(0.000)$ & $(0.000)$ \\
$\mathrm{R}^{2}$ & 400 & 451 \\
GB£ & 0.982 & 0.997 \\
\hline
\end{tabular}

$* * * \mathrm{p}<0.01, * * \mathrm{p}<0.05, * \mathrm{p}<0.1$. (Robust standard errors in parentheses.)

$\Delta \mathrm{EMP} \equiv \Delta \log H_{t}+(\Delta \operatorname{Res}) / M B_{\mathrm{t}}$ (daily interpolation). 
2.3 Singapore: Identifying Break Points in Singapore's Exchange Rate Regime Daily M8:2005-M2:2017

\begin{tabular}{|c|c|c|c|c|}
\hline VARIABLES & $\begin{array}{c}(1) \\
8 / 2 / 2005-11 / 9 / 2006\end{array}$ & $\begin{array}{c}(2) \\
11 / 10 / 2006-1 / 8 / 2008\end{array}$ & $\begin{array}{c}(3) \\
1 / 9 / 2008-3 / 2 / 2009\end{array}$ & $\begin{array}{c}(4) \\
3 / 3 / 2009-5 / 4 / 2010\end{array}$ \\
\hline US\$ & $\begin{array}{c}0.468 * * * \\
(0.117)\end{array}$ & $\begin{array}{c}0.575^{* * *} \\
(0.135)\end{array}$ & $\begin{array}{c}0.154 \\
(0.144)\end{array}$ & $\begin{array}{l}-0.293 \\
(0.469)\end{array}$ \\
\hline Euro $€$ & $\begin{array}{c}0.137^{* * *} \\
(0.034)\end{array}$ & $\begin{array}{c}0.280 * * * \\
(0.041)\end{array}$ & $\begin{array}{c}0.294^{* * *} \\
(0.026)\end{array}$ & $\begin{array}{c}0.298 * * * \\
(0.028)\end{array}$ \\
\hline$J P Y$ & $\begin{array}{c}0.191^{* * *} \\
(0.024)\end{array}$ & $\begin{array}{l}-0.032 \\
(0.021)\end{array}$ & $\begin{array}{c}0.009 \\
(0.021)\end{array}$ & $\begin{array}{l}-0.002 \\
(0.019)\end{array}$ \\
\hline $\mathrm{CN} \mathrm{Y}$ & $\begin{array}{c}0.118 \\
(0.119)\end{array}$ & $\begin{array}{c}0.095 \\
(0.136)\end{array}$ & $\begin{array}{c}0.465^{* * *} \\
(0.147)\end{array}$ & $\begin{array}{l}0.905^{*} \\
(0.473)\end{array}$ \\
\hline$\triangle \mathrm{EMP}$ & $\begin{array}{c}0.289 * * * \\
(0.034)\end{array}$ & $\begin{array}{c}0.181^{* * *} \\
(0.029)\end{array}$ & $\begin{array}{c}0.410 * * * \\
(0.042)\end{array}$ & $\begin{array}{c}0.121 * * * \\
(0.024)\end{array}$ \\
\hline Constant & $\begin{array}{c}-0.001 * * * \\
(0.000)\end{array}$ & $\begin{array}{c}-0.001^{* * *} \\
(0.000)\end{array}$ & $\begin{array}{c}-0.001 * * * \\
(0.000)\end{array}$ & $\begin{array}{l}-0.000^{*} \\
(0.000)\end{array}$ \\
\hline Observations & 319 & 289 & 289 & 295 \\
\hline $\mathrm{R}^{2}$ & 0.899 & 0.782 & 0.929 & 0.892 \\
\hline GB£ & 0.086 & 0.082 & 0.077 & 0.092 \\
\hline
\end{tabular}

\begin{tabular}{lccc}
\hline & $(5)$ & $(6)$ & $(7)$ \\
VARIABLES & $5 / 5 / 2010-8 / 19 / 2011$ & $8 / 22 / 2011-3 / 1 / 2013$ & $3 / 4 / 2013-2 / 28 / 2017$ \\
\hline US $\$$ & $0.376^{* * *}$ & $0.218^{*}$ & $0.379^{* * *}$ \\
& $(0.084)$ & $(0.113)$ & $(0.033)$ \\
Euro $€$ & $0.324^{* * *}$ & $0.309^{* * *}$ & $0.316^{* * *}$ \\
& $(0.019)$ & $(0.029)$ & $(0.011)$ \\
JP Y & $0.048^{* * *}$ & $0.057^{* *}$ & $0.081^{* * *}$ \\
& $(0.018)$ & $(0.028)$ & $(0.008)$ \\
CN Y & $0.166^{* *}$ & $0.189^{*}$ & $0.100^{* * *}$ \\
& $(0.082)$ & $(0.106)$ & $(0.032)$ \\
$\Delta$ EMP & $0.477^{* * *}$ & $0.314^{* * *}$ & $0.724 * * *$ \\
& $(0.027)$ & $(0.026)$ & $(0.017)$ \\
Constant & $-0.001^{* * *}$ & $-0.000^{* * *}$ & $-0.000^{* * *}$ \\
& $(0.000)$ & $(0.000)$ & $(0.000)$ \\
Observations & 325 & 383 & 998 \\
$\mathrm{R}^{2}$ & 0.872 & 0.645 & 0.934 \\
GB£ & 0.085 & 0.227 & 0.124 \\
\hline
\end{tabular}

$* * * p<0.01, * * p<0.05, * p<0.1$. (Robust standard errors in parentheses.)

$\Delta \mathrm{EMP} \equiv \Delta \log H_{t}+(\Delta R e s) / M B_{t}$ (daily interpolation). 
2.4 South Korea: Identifying Break Points in South Korea 's Exchange Rate Regime Daily M8:2005-M2:2013

\begin{tabular}{|c|c|c|c|c|}
\hline & (1) & (2) & (3) & (4) \\
\hline VARIABLES & $8 / 2 / 2005-3 / 17 / 2008$ & $3 / 18 / 2008-1 / 2 / 2009$ & $1 / 5 / 2009-5 / 3 / 2010$ & $5 / 4 / 2010-2 / 1 / 2013$ \\
\hline \multirow[t]{2}{*}{ US \$ } & $0.239 * *$ & $1.478 * * *$ & -0.636 & $0.307^{* * *}$ \\
\hline & (0.099) & $(0.444)$ & (0.411) & $(0.050)$ \\
\hline \multirow[t]{2}{*}{ Euro $€$} & $0.293 * * *$ & $0.443 * * *$ & $0.345^{* * *}$ & $0.384 * * *$ \\
\hline & $(0.030)$ & $(0.118)$ & $(0.030)$ & $(0.012)$ \\
\hline \multirow[t]{2}{*}{$J P Y$} & $0.077 * * *$ & 0.063 & $0.083 * * *$ & $0.108^{* * *}$ \\
\hline & $(0.018)$ & $(0.092)$ & $(0.020)$ & $(0.010)$ \\
\hline \multirow[t]{2}{*}{$\mathrm{CN} \mathrm{Y}$} & $0.310 * * *$ & $-1.016^{* *}$ & $1.125^{* * *}$ & $0.122^{* *}$ \\
\hline & $(0.101)$ & $(0.437)$ & $(0.414)$ & $(0.050)$ \\
\hline \multirow[t]{2}{*}{$\triangle E M P$} & $0.661 * * *$ & $0.872 * * *$ & $0.858 * * *$ & $0.938 * * *$ \\
\hline & $(0.029)$ & $(0.053)$ & $(0.027)$ & $(0.010)$ \\
\hline \multirow[t]{2}{*}{ Constant } & $-0.001 * * *$ & $0.004 * * *$ & $-0.004 * * *$ & $-0.001 * * *$ \\
\hline & $(0.000)$ & $(0.001)$ & $(0.000)$ & $(0.000)$ \\
\hline Observations & 657 & 199 & 335 & 690 \\
\hline$R^{2}$ & 0.875 & 0.842 & 0.919 & 0.953 \\
\hline GBE & 0.082 & 0.032 & 0.084 & 0.080 \\
\hline
\end{tabular}

We hope to extend this research further -- Frankel and Xie (2017) -- by incorporating estimation of a possible target zone, appropriate for a country that might be following a band or target zone, perhaps together with a basket. The target zone is incorporated into the equation by means of the Threshold Autoregression Technique. 


\section{c. How do these analyses depend on the use of intervention data versus reserve changes? The case of Turkey}

It is easy enough to write down in theory that the magnitude of foreign exchange intervention equals the change in reserves. Many central banks do not report data on foreign exchange intervention operations, as opposed to data on reserves. For this reason, although empirical research on foreign exchange intervention per se usually focuses on the few countries and time samples where the data are available, the literature on exchange rate regimes often uses data on monthly changes in reserves, which are reported by almost all countries.

In practice, data on intervention, even when explicitly reported, tend to look very different from data on changes in foreign exchange reserves. In this section we seek to shed light on the question how much difference it makes whether one uses data on intervention or foreign exchange intervention, when assessing whether a country follows a systematically managed float.

There are two obvious reasons to expect the data on foreign exchange intervention to differ from the data on changes in foreign exchange reserves, reasons why reserves will change even if there has been no intervention. The first is that interest accrues on the central bank's holdings of US treasury bills and other assets held as foreign exchange reserves. The second is the valuation effect: If the value of reserves is measured in terms of domestic currency, it will change every time the exchange rate changes.

Even when the monetary authority does not report the value of reserves in terms of foreign currency, if all the reserves are known to be held in US treasury bills the researcher can use the monthly exchange rate to infer how much of a reported change in reserves is due to the pure valuation effect. But most central banks hold at least some of their reserves in other assets and few if any accommodate researchers by reporting the currency composition. Furthermore it has become more common in recent years for central banks to diversify out of US treasury bills, not just into other non-US currencies but also into other securities, such as longer-term bonds and even equities in some cases. This exacerbates each of the two measurement problems: earnings on the reserves are generally higher on these alternate assets than on US treasury bills, and valuation effects now include capital gains and losses on securities beyond just exchange rate changes.

When one looks into the data one always finds a variety of further complications, some of which suggest that what counts as intervention is not just an issue of having access to the right data, but can be an issue of conceptual interpretation too. To take an example, some developing countries have official agencies that sell the country's commodity exports for 
dollars. If the agency chooses to hold the dollars (e.g., in a sovereign wealth fund), rather than exchange them for the local currency, does that count as foreign exchange intervention or as the absence of foreign exchange intervention? Something analogous apparently holds in the case of Turkey, a country to which we are about to turn: an official agency holds dollars for the purpose of importing oil.

We turn to Turkey because it is one of the only managed floaters that also regularly makes public its data on foreign exchange intervention. Most countries only publish monthly data on foreign exchange reserves.

We want to see how much difference it makes when studying the central bank's behavior with respect to the foreign exchange market whether one uses intervention data or reserve changes. We know that the two series will differ. But, in the context of classifying countries by exchange rate regime, we want to be able to distinguish within the broad class of floaters those that systematically manage their floats, versus those that float freely or only intervene unsystematically. To do that, we want to get an idea whether it makes a difference whether one uses the reserve data versus the intervention data.

It might be natural to think of the exercise as seeing whether the commonly available reserve data give the "right answer" represented by the more rarely available intervention data. But one could argue, in the context of classifying exchange rate regimes, that the foreign exchange reserves have at least as much a claim to being the right measure as intervention data. Recall the framework for thinking about the continuum of fixed versus flexible exchange rates that goes under the name of Exchange Market Pressure. Exchange Market Pressure (EMP) is defined as a weighted average of the percentage change in the foreign exchange value of the currency and the change in foreign exchange reserves (where the weight on foreign exchange reserves might variously be defined as the inverse of the monetary base, as the inverse relative standard deviation, or as an endogenously estimated parameter). EMP represents the increase in demand for domestic currency versus foreign currency. It is up to the central bank whether to allow exchange market pressure (EMP) to show up entirely in the form an appreciation of the currency, which is floating; or entirely as an increase in foreign exchange reserves, which is fixing; or somewhere in between. If it consistently acts to absorb some share between zero and one in the exchange rate and the remainder in reserves, then we deem it to be a systematically-managed floater. For this purpose, it is the change in reserves that matters, not intervention normally defined. Again, if reserves rise because of interest earned on US Treasury bills, that is not considered foreign exchange intervention, but may be relevant nonetheless.

Others have studied the Turkish intervention data. Basu and Varoudakis (2013) find a clear reaction function that shows systematic management of the floating lira: Turkish 
intervention responds to the level of the exchange rate (nominal effective), as is visible in Figure 4, borrowed from their paper. Frömmel and Midiliç (2016) similarly find statistically significant reaction of intervention to the level of the exchange rate relative to a trend (medium run moving average), but no reaction to the recent rate of change of the exchange rate. Their main focus is on an additional variable, the level of foreign exchange reserves relative to GDP. They find that it is a significant determinant of Turkish intervention. They also identify several significant structural breaks in the reaction function.

As they explain, the monetary authority, the Central Bank of the Republic of Turkey, undertakes two different modes of foreign exchange intervention: occasional auctions and regular market operations. On many days, the number for the auction is zero. We add the two together to get the measure of intervention. The series is still jagged because of the auctions. Thus we smooth out the data a bit, by looking at monthly averages or other moving averages, as other studies have done.

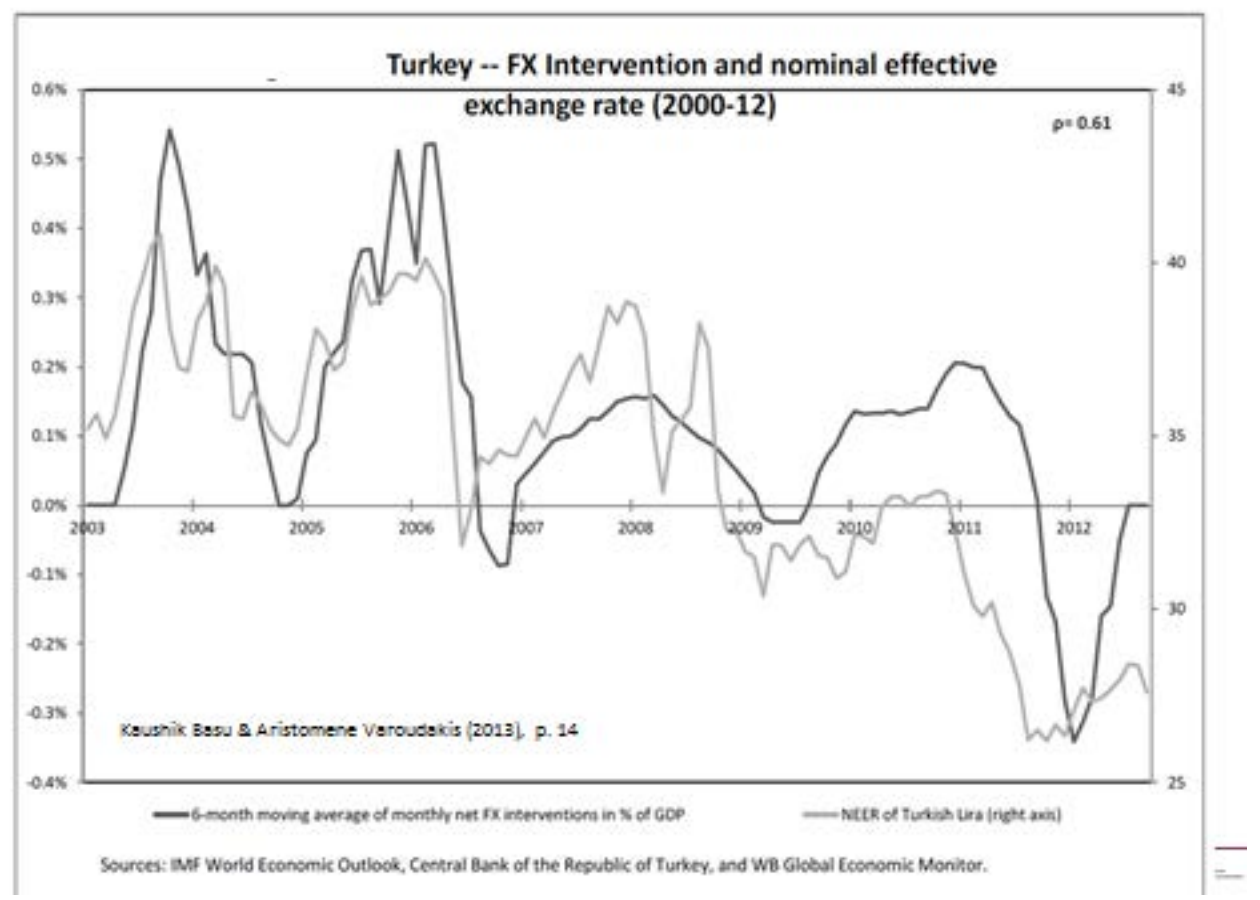

Figure 4: Turkey's systematic management of its float (from Basu and Varoudakis, 2013)

Figure 5 graphs the two different measures of intervention, along with various measures of the exchange rate. The two measures look quite different, as expected, but are highly correlated. 


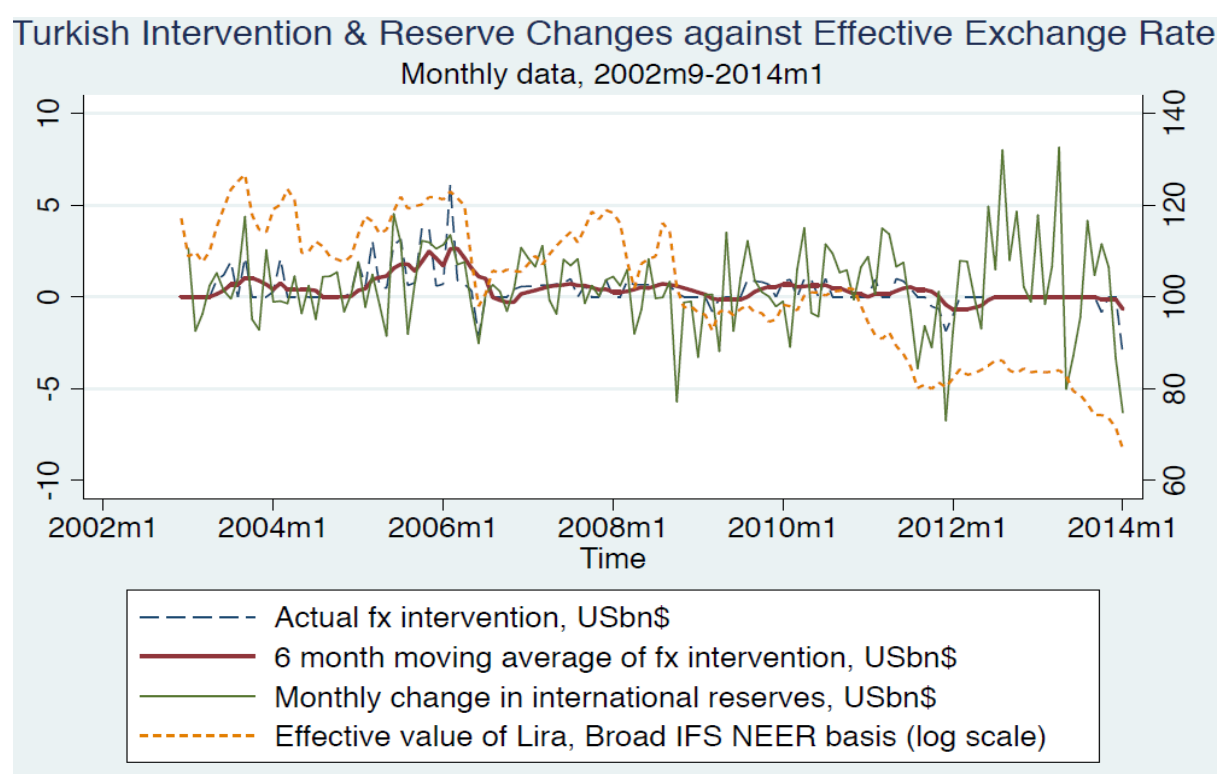

Figure 5: Foreign Exchange Actions by Turkey: Intervention Data vs. Reserve Changes

Several hypotheses are tested for the central bank reaction function. A particular sort of systematic behavior is flow intervention that seeks to drive the exchange rate in the direction of its long run equilibrium. This means buying foreign currency when the price of foreign currency, which is the exchange rate, is low (the value of the domestic currency is high), measured relative to either a long-run average or a long-run trend, and selling foreign currency when the price of foreign currency is high (the value of the domestic currency is low). But an alternative is "leaning against the wind," which is usually interpreted as intervention that opposes the most recent direction of movement of the exchange rate, as opposed to its level. A third relevant variable is the level of reserves. Research on reserve holdings features the hypothesis that central banks have a target level of reserves ${ }^{28}$, held for precautionary purposes, and that the motivation for intervention behavior is not just to affect the exchange rate but also to move reserves in the direction of the target level. There has been some evidence in favor of this hypothesis, particularly since the currency crises of the 1990s and particularly in the case of Turkey (Frömmel and Midiliç, 2016, as noted). A fourth relevant variable is the inflation rate, under the hypothesis that, in an inflation targeting country, central bank operations in the foreign exchange market are among the tools that are motivated by an effort to push the inflation rate in the direction of its target.

28 References on central bank's desired reserve holdings include Jeanne and Rancière (2011) and Rodrik (2006), 
The full equation is thus:

$\mathrm{FX}$ acquisition $=\gamma+\alpha\left(\mathrm{s}_{\mathrm{t}}-\mathrm{s}_{\text {trend }}\right)+\beta\left(\mathrm{s}_{\mathrm{t}}-\mathrm{st}_{\mathrm{t}-1}\right)+\delta(\text { Res } / \mathrm{GDP})_{\mathrm{t}}+\psi($ inflation - target $)$

The dependent variable, "Acquisition of foreign exchange," is measured either by the data on foreign exchange intervention or by changes in foreign exchange reserves.

Regression results are reported in Table 3. Several conclusions emerge. When the rate of change variable is included on its own (Table 3.1), to test for "leaning against the wind," it is highly significant regardless whether the dependent variable is measured by intervention or changes in reserves. When the level of the exchange rate is included on its own (Table 3.2), it is highly significant for explaining Intervention and borderline-significant for explaining reserve changes. When both variables are included at the same time, there is evidence in favor of both (Table 3.3). When the central bank's behavior is judged by the intervention data, both the level and rate of change variables are significant. When it is judged by reserve changes, the rate of change variable is highly significant but the level variable is at best borderline-significant.

When the ratio of reserves/GDP is included to test the hypothesis of a target level (Table 3.3), the intervention data give strong support: the effect is negative and significant, thus suggesting that the authorities are more likely to add to their reserves when the level is low. The effect is not evident when central bank behavior is measured by the change in reserves, rather than the intervention data. Estimates for sub-periods are reported in the on-line appendix table (Sheets 7 and 8 ).

We find no evidence for the inflation targeting hypothesis: Neither intervention nor changes in reserves appear to respond significantly to the level of inflation measured relative to its target. This finding is of interest since Turkey is supposedly an inflation-targeter. We omitted the inflation results from the equation estimates reported in table 3 , but they are included in the on-line appendix (Sheet 10). 


\section{Table 3: Estimating Foreign Exchange Reaction Function of Turkey's Central Bank monthly observations: $2003 \mathrm{~m} 1-2014 \mathrm{~m} 1$}

Table 3.1 Regressing Turkish intervention measures against only against $\mathrm{s}_{\mathrm{t}}-\mathrm{s}_{\mathrm{t}-1}$.

\begin{tabular}{|c|c|c|}
\hline Dependent Variable & $\underline{\text { Intervention }}$ & $\Delta$ Reserves \\
\hline \multirow[t]{2}{*}{$S_{t}-S_{t-1}$} & $6.017 * *$ & $24.568 * * *$ \\
\hline & $(2.388)$ & $(5.527)$ \\
\hline \multirow[t]{2}{*}{ Constant } & $0.408 * * *$ & $0.645^{* * *}$ \\
\hline & (0.098) & $(0.200)$ \\
\hline
\end{tabular}

Observations

133

133

Table 3.2 Regressing Turkish intervention measures against only $s_{t}-s_{\text {trend }}$.

Dependent Variable Intervention

$\underline{\Delta \text { Reserves }}$

$\begin{array}{ccc}\mathbf{S}_{\mathrm{t}}-\text { Strend } & 3.240 * * * & 3.776 * \\ & (0.871) & (2.034) \\ \text { Constant } & 0.390 * * * & 0.577 * * * \\ & (0.094) & (0.215)\end{array}$

Observations

134

133

Table 3.3. Regressing Turkish intervention measures against both $\left(\mathrm{s}_{\mathrm{t}}-\mathrm{s}_{\mathrm{t}-1}\right)$ and $\left(\mathrm{s}_{\mathrm{t}}-\mathrm{s}_{\mathrm{trend}}\right)$. Dependent Variable Intervention Intervention Intervention $\underline{\text { Reserves }}$

\begin{tabular}{|c|c|c|c|c|}
\hline$S_{t}-S_{t-1}$ & $\begin{array}{c}4.403 * * \\
(1.947)\end{array}$ & & $\begin{array}{c}2.959 \\
(1.816)\end{array}$ & $\begin{array}{c}24.851^{* * *} \\
(5.497)\end{array}$ \\
\hline$S_{t}-S_{\text {trend }}$ & $\begin{array}{c}3.017^{* * *} \\
(0.831)\end{array}$ & $\begin{array}{c}2.338 * * * \\
(0.867)\end{array}$ & $\begin{array}{c}2.264^{* * *} \\
(0.855)\end{array}$ & $\begin{array}{l}3.196 * \\
(1.754)\end{array}$ \\
\hline Reserves/GDP & Res/GDP & & $\begin{array}{c}-4.445^{* * *} \\
(1.556)\end{array}$ & $\begin{array}{c}-4.070 * * \\
(1.566)\end{array}$ \\
\hline Constant & $\begin{array}{c}0.399 * * * \\
(0.093)\end{array}$ & $\begin{array}{c}2.256 * * * \\
(0.668)\end{array}$ & $\begin{array}{c}2.105^{* * *} \\
(0.673)\end{array}$ & $\begin{array}{l}-1.203 \\
(1.481)\end{array}$ \\
\hline Observations & 133 & 134 & 133 & 133 \\
\hline
\end{tabular}

t-statistic significant at: $* 10 \%$ level $* * 5 \%$ level $* * * 1 \%$ level . (Newey-West standard errors.) Intervention is measured in $\$$ billions. Exchange rates $\mathbf{S}_{\mathbf{t}}$ are in logs.

Note: A more complete set of results is reported in an on-line Turkey Appendix. It includes, for example, tests for evidence that foreign exchange intervention is influenced by inflation relative to an inflation target. It also allows for three structural breaks, with the dates taken from Frömmel and Midiliç (2016): 2007m10-2011m7, 2011m8-2013m6, 2013m7-2014m1. Thanks to Shruti Lakhtakia. 
To conclude, we get slightly different answers when we use intervention data to investigate the reaction function of the Central Bank of the Republic of Turkey from the answers when we use data on reserve changes. But in both cases, qualitatively, we find evidence of a systematic effort to dampen volatility of the exchange rate.

\section{Effects of external shocks}

Do countries that systematically and aggressively manage their floats succeed in dampening fluctuations in the real exchange rate? Or is the exchange rate regime a mirage, as some claim?

Of course there is already quite a lot of evidence that exchange rate regimes make a difference, that a regime that allows bigger changes in the nominal exchange rate will thereby allow bigger changes to the real exchange rate. ${ }^{29}$

A number of recent papers look at capital inflows to emerging markets, often gross capital inflows, and study the response of the local monetary authorities, including with respect to exchange rate flexibility. ${ }^{30}$ We focus on the overall balance of payments instead of gross capital inflows. For one thing, the distinction between an increase in foreign assets in the domestic country and a decrease in foreign liabilities can be arbitrary, not just in an accounting sense but even conceptually, especially when it comes to banking flows. For another thing, a positive external commodity shock is often reflected in both a trade surplus and a capital account surplus.

The only way to solve the endogeneity problem is to use a truly exogenous variable like US interest rates, the VIX, or dollar commodity prices. The severely endogenous nature of the capital inflows or overall balance of payments is widely recognized: If the authorities choose to respond to a positive shock by allowing the currency to appreciate, that may operate to shut off the inflow. If one has such an exogenous variable, there is a strong case for putting it directly on the right-hand side of an OLS equation. This is especially clear when the country is a pure floater, as Australia and New Zealand in our sample, in which case the comprehensive aggregate measure of inflows, i.e., the balance of payments, should be zero by definition of floating.

${ }^{29}$ Convincing empirical results from different approaches include Mussa (1986), Taylor (2002), and Bahmani-Oskooee, Hegerty and Kutan (2008). The reasons why the exchange rate regime makes a difference can come from imperfect goods markets.

30 Including Milesi-Ferretti and Tille (2011), Magud, Reinhart, and Vesperoni (2014), Blanchard, Adler, and de Carvalho Filho (2015), and Blanchard, Ostry, Ghosh, and Chamon (2016). 


\section{a. Effects on the real exchange rate}

The core exercise of the paper is to test the effects of exogenous external shocks on the real exchange rate, using time series for a select set of countries, and then to see if the sensitivity to shocks is different according to the country's exchange rate regime. The null hypothesis is that the regime makes no difference: that a shock will have the same effect on the real exchange rate regardless whether the nominal exchange rate is fixed, in which case it must show up in the price level, or floating, in which case it shows up directly in the nominal exchange rate. The alternative hypothesis is that shocks have a bigger effect on the real exchange rate under floating than under managed floating and a bigger effect under managed floating than under fixing.

It is crucial for this exercise that the measured shocks are truly and credibly exogenous on their face. We focus on two measures: dollar commodity prices and the VIX. ${ }^{31}$ The VIX is a measure of market perceptions of near-term volatility extracted from put and call options on the US S\&P 200 stock index and traded on the Chicago Board of Exchange.

For the tests where commodity prices are taken to be the main exogenous variable, we restrict the sample to countries where a high percentage of exports is concentrated in a small number of commodities (energy, mineral or agricultural). For some, particularly oil exporters, that is a single commodity; for others it is several commodities. We construct a tailor-made monthly price index for each country by computing weights as the average commodity shares in exports during the sample period and then multiplying them by monthly dollar prices of the corresponding commodities. (The data appendix gives details.)

We do not want to attempt a comprehensive study of all countries. ${ }^{32}$ For one thing, we seek only those with compelling measures of exogenous external shocks [to be used either as instrumental variables or directly as independent variables In the real exchange rate regressions]. That narrows down the set of countries. We have good reason to think that commodity prices are important to commodity producing countries. Beyond the simple evidence of the share of the commodities in the countries' output, a number of empirical

${ }^{31}$ Other possible measures of exogenous shocks include a broader measure of financial risk perceptions, US interest rates, and (for some countries) natural disasters. We tried the Global Economic Policy Uncertainty, but it did not add any explanatory power beyond the VIX. We use dollar prices of the country's export commodities rather than a more comprehensive measure of its terms of trade because the former is plausibly exogenous (except perhaps for Saudi Arabia) as in the small open economy model, whereas measures of the terms of trade are in practice likely to be endogenous with respect to the nominal exchange rate.

32 We may eventually try a panel study within our set of countries. 
papers have confirmed that when the currencies of commodity-producing countries are allowed to float, they tend to rise and fall with the global prices of the commodities. ${ }^{33}$

A number of other studies have found that countries that export volatile-price commodities perform better with floating or managed floating exchange rates than with fixed rates, ${ }^{34}$ which leads us to anticipate that the exchange rate regime will indeed make a difference.

Commodities are not as important for most Asian countries as for most in Latin America, Africa or the Middle East. (Commodities used to be very important in Southeast Asia, but have been somewhat displaced by manufactures in most of the region.) For Asian countries we can use the VIX. Many studies have found that the VIX, reflecting the risk-sensitivity of global investors along the "risk-on" vs. "risk-off" spectrum, is an important determinant of EM capital flows and, especially, of Emerging Market exchange rates and securities prices. ${ }^{35}$

Another dimension along which we seek deliberately to narrow down the set of countries is by the clarity of the exchange rate regime and the length of time that the country has maintained it. We are especially interested in those that have firm pegs and those that are good candidates for either systematically managed floating or free floating. (We recognize that very few fall in the latter category, among developing countries.) To make the first cut -- identifying firm pegs and a group of floaters broadly defined -- we rely on standard classification schemes, particularly the most recent from llzetzki, Reinhart and Rogoff (2017). We deliberately drop those countries that change regimes every couple of years or have no clear regime at all, such as the free-fallers of Reinhart and Rogoff. But we wish to use our own criteria to distinguish countries that float freely (or virtually freely), such as New Zealand, and those that systematically manage their floats, such as Turkey. We want to omit those that intervene irregularly and unsystematically.

33 Including Cashin, Céspedes, and Sahay (2004), Chen and Rogoff (2003), and Frankel (2007).

34 Including Broda (2004), Edwards and Levy-Yeyati (2005), Rafiq (2011), and Céspedes and Velasco (2012).

35 They include Baskaya, di Giovanni, Kalemli-Ozcan, and Ulu (2017), Cerutti, Claessens, and Puy (2015), Forbes and Warnock, 2012) and Fratzscher (2012). Miranda-Agrippino and Rey (2015) and Rey (2015) trace these fluctuations in the global financial environment to changes in US monetary policy. Chari, Stedman and Lundblad (2017) find that the shocks do not show up in the quantity of capital flow so much as they drive EM asset prices. 


\section{b. Estimates for some Asian countries}

We start with a set of eight Asian economies that are not primarily commodityexporters for the period January 1997-December 2015. Regression results are reported in Appendix A. A few Asia/Pacific countries that are commodity producers will be considered below, where the sample will also have the advantage of several pure floaters and a number of firm fixers.

We start in Table A1 with an OLS regression of the real exchange rate directly against our external shock measure for the non-commodity countries: log (VIX). Because of the highly autoregressive nature of the real exchange rate, we include a lagged endogenous variable, without which apparent significant levels would be spuriously high. ${ }^{36}$ Even so, the VIX is statistically significant, with the hypothesized negative effect on the real exchange rate, defined here as the value of the local currency: An adverse shock in global financial market conditions causes a real depreciation. That is, we get the hypothesized negative effect for these 7 countries, all of which can be classified as systematic managed floaters: India, Korea, Malaysia, Philippines, Singapore, Thailand and Turkey. (The strongest effects are shown for Korea, followed by the Philippines, Thailand and Turkey.)

The one economy for which the coefficient is neither negative nor significant is precisely the one economy for which that is the hypothesis. Hong Kong, which has a firm peg to the dollar, shows no effect. To find no effect on the nominal exchange rate would tell us little. Finding zero effect on the real exchange rate confirms that regimes do matter for real variables, and that a peg prevents the real depreciation that the seven flexible-rate currencies experience.

Table A2 regresses the Real Exchange Rate for the Asian countries against the balance of payments (measured as the change in foreign exchange reserves) as a ratio to GDP (expressed

\footnotetext{
${ }^{36}$ The estimated coefficients on the lagged Real Exchange Rate are all high, as expected. Some appear statistically less than 1.0, some do not. A statistical failure to reject 1 is usually considered evidence of a unit root in the real exchange rate. If the real exchange rate truly has a unit root, then the equation should be estimated in first differences, or using more sophisticated time series techniques. Many studies have documented on long time samples that real exchange rates in truth have a tendency to regress slowly to an equilibrium level (represented by an average or trend), but that 20 years of data nevertheless do not have enough statistical power to reject a random walk. There is a trade-off between the danger of spurious results on the one hand and the danger of throwing out perfectly good information on the other hand. Standard practice is that one should err on the side of rooting out unit roots (though the author is not aware of what research supports the general presumption that this is the greater danger). We hope in the future to refine the results in this paper with a more sophisticated time series approach.
} 
in common currency units). ${ }^{37}$ We still think of log (VIX) as the driving exogenous shock, but now it is the instrumental variable for the balance of payments. The estimated coefficients are now positive in every case, as they should be: a balance of payments surplus (resulting from a fall in the VIX) shows up in part as an appreciation of the local currency. However most of the coefficients now lose their statistical significance. Only in Korea and Turkey are the effects on the real exchange rate still highly significant statistically. The problem may lie in a weak firststage instrument (especially in cases such as the Philippines and Thailand, judging by first-stage F-statistics.)

\section{c. Estimates for commodity-exporting countries}

Next we turn to estimates for a set of 21 commodity-exporting countries, reported in Appendix Table B. We have reason to hope that the exogenous variable will be a stronger instrument here, especially since we compute for each country an index of international commodity prices that is tailor-made to correspond to the commodity composition of its exports.

Table B1 reports the OLS regressions of the real exchange rate against the individual commodity price indices. The set of 21 includes three pure floaters: Australia, Canada and New Zealand. All three show highly significant effects on their real exchange rates, confirming their role as "commodity currencies." Chile also floated during much of this period, but not all, which may explain why its coefficient is only of borderline significance.

Of the countries that show no significant effect, four are firm fixers as one would expect: Ecuador, the UAE, Bahrain and Qatar (all pegged to the dollar). But South Africa also shows no significant effects here even though it is a systematic managed floaters by our criteria, while Brunei and Saudi Arabia show significant effects even though they are firm peggers (to the Singapore dollar and the US dollar, respectively). ${ }^{38}$

For Indonesia, Papua New Guinea, Kazakhstan, Mongolia, and the rest of the 8 countries with managed floats or other intermediate regimes, the effect of the commodity price is statistically significant and positive.

\footnotetext{
37 Now the lagged Real Exchange Rate shows estimated coefficients that are very close to 1.0. Thus one might think of the equation as essentially regressing the change in the real exchange rate against the change in reserves.

${ }^{38}$ Brunei sometimes shows a significant positive effect, contrary to the hypothesis for a pegger. But this is probably because it is pegged to Singapore, which is a sort of managed floater.
} 
Since many of these countries not only export commodities but also participate in international financial markets and thus qualify as emerging markets, Table B2 adds the VIX as an additional regressor. The results for the commodity price coefficient are similar. The VIX shows up with a significant RER effect for a few countries, all of them floaters. It is (just) significant for Colombia, one of the commodity-exporting intermediate-regime countries that did not show a significant responsiveness of the real exchange rate in Table B1.

Next we consider the regressions of the real exchange rate against the balance of payments, with both the country-specific commodity price index and the VIX as instrumental variables. We need a denominator for the balance of payments. We start with GDP in Table B3, which is perhaps the most obvious scale variable. But in Tables B4 and B5 we use M1 and the monetary base, respectively, as the denominator for the change in reserves, thereby linking up with the idea of Exchange Market Pressure. ${ }^{39}$

We want to distinguish the results for managed floaters as compared to firm fixers. The three free floaters (Australia, Canada and New Zealand) have been discarded, since floating implies by definition that the balance of payments is zero. Five managed floaters show significant effects on the real exchange rate in these three tables: Brazil, Chile, Colombia, Russia and South Africa. Two firm fixers show insignificant effects, again as hypothesized: Brunei and Ecuador.

Some show the anomalous result of a significant negative coefficient. In the case of a systematic managed floater like Peru, the result is indeed anomalous

An explanation is available why the coefficient estimates are negative for many of the Gulf countries and significantly so in the case of Saudi Arabia. ${ }^{40}$ For these countries, the export commodity basket index consists simply of the dollar price of oil (or oil and natural gas). Even though oil and gas are priced and invoiced in dollars, the dollar price of oil falls quickly after an appreciation of the dollar against the euro, yen and other major currencies - as one would expect since Europe and Japan are major buyers of oil and gas. Bahrain, Qatar, the UAE and Saudi Arabia are all pegged specifically to the dollar. When the dollar appreciates against the euro, yen and other currencies, so do the dinar, dirham, and riyal. The implication is a negative correlation between the trade-weighted exchange rate, which is the one that goes into the

\footnotetext{
${ }^{39}$ When a country is missing from a table, it is due to data availability. See on-line data appendix.

${ }^{40}$ There is a second possible explanation for anomalous results in the case of Saudi Arabia. It alone among all the commodity producers is large enough in the world market for its export commodity, oil, that we might want to question the assumption that the world price is exogenous. But the first reason seems a good enough explanation.
} 
regressions, and the dollar price of oil. This suggests that the dollar peg does worse than fail to accommodate terms of trade shocks; it actually tends to move in the wrong direction. (The Gulf countries might be better off pegging to a more sophisticated basket. $)^{41}$

Perhaps something like this explanation also applies to Azerbaijan and Kazakhstan, since both are oil exporters. But these two are neither firm fixers nor managed floaters. Both of them have in recent years repeatedly tried to target their exchange rates and then been forced belatedly into large devaluations by alarming reserve losses. In this paper we are concerned with the three special categories of firm fixers, free floaters and systematically-managed floaters. We have no hypothesis regarding those that fall outside these three categories.

\section{d. Summary of conclusions}

A majority of countries follow exchange rate policies that can be designated as "intermediate," in that they are neither firm-fixers nor free-floaters. But this paper proposes the designation "systematically managed floater" only for those countries where the monetary authorities tend consistently to react to exchange market pressure with some proportion of change in the exchange rate and some proportion of change in foreign exchange reserves. A sub-set of the intermediate regimes can be identified as meeting statistical criteria along the lines of this definition (Part 2 of the paper).

In some theories, shocks will have the same effect on the real exchange rate regardless of regime, showing up in the exchange rate under floating but showing up in the price level if the exchange rate is fixed. A hypothesis of the paper is that exchange rate regimes do make a difference for the behavior of the real exchange rate. Specifically, an exogenous positive shock does not affect the real exchange rate in the short run if the nominal exchange rate is fixed, but will cause a real appreciation under a systematic managed float, with the magnitude of the real appreciation depending on how heavily managed is the float.

Our empirical tests focus on two kinds of shocks, measured by the VIX and export commodity prices. We have not attempted a comprehensive panel study. There are many reasons to view the various statistical results of this paper as rudimentary, particularly with respect to the familiar problems of causality and non-stationarity.

But some of the results in Part 3 of the paper tend to support the hypothesis:

- Most EM economies with firmly fixed exchange rates do not experience real appreciation during periods of inflow arising from positive external shocks, such as 2003-08 or 2010-11,

${ }^{41}$ Frankel (2017). 
nor do they experience real depreciation during periods of outflow arising from negative external shocks such as 2008-09 or 2014-15. Of the firm-fixers, the case where the primary exogenous variable is the VIX is Hong Kong. The firm-fixers where it is the export commodity price include Ecuador and the Gulf countries.

- For our free-floating commodity exporters - Australia, Canada and New Zealand - positive shocks in their country-specific export commodity price index cause real appreciation of their currencies.

- For our systematic managed floaters in Asia, particularly Korea and Turkey, a fall in the VIX leads to real appreciation, regardless of whether observed directly (OLS) or indirectly via the balance of payments surplus (IV). For the others -- India, Malaysia, the Philippines, Singapore and Thailand -- -- the effect is statistically significant only when observed directly.

- For our commodity exporting managed floaters, the effects vary, but are significantly greater than zero more often than among the firm fixers and less often than the free floaters.

In short, we reject the view that exchange rate regimes make no difference. We find that positive external shocks tend to cause real appreciation for most systematic managed-floaters; more strongly so for pure floaters; and not at all for most firm peggers. 


\section{$\underline{\text { References }}$}

Adler, Gustavo, Noemie Lisack and Rui Mano, 2015, "Unveiling the Effects of FX Intervention: A Panel Approach." IMF Working Paper No. 15/130.

Adler, Gustavo and Camilo E. Tovar, 2011, "FX Intervention: A Shield against Appreciation Winds?" IMF Working Paper No. $11 / 165$.

Aizenman, Joshua, Menzie Chinn, and Hiro Ito. 2010. "The Emerging Global Financial Architecture: Tracing and Evaluating New Patterns of the Trilemma Configuration." Journal of International Money and Finance 29(4), pp. 615-641.

Aizenman, Joshua, Menzie Chinn, and Hiro Ito. 2011. "Surfing the Waves of Globalization: Asia and Financial Globalization in the Context of the Trilemma," Journal of the Japanese and International Economies 25(3), pp. 290-320.

Bahmani-Oskooee, M., S.Hegerty and A.Kutan, 2008, "Do Nominal Devaluations Lead to Real Devaluations? Evidence from 89 Countries" International Review of Economics and Finance 17, 644-70.

Bai, Jushan and Pierre Perron. 2003. "Computation and analysis of multiple structural change models," Journal of Applied Econometrics, 18(1): 1-22.

Baskaya, Yusuf Soner, Julian di Giovanni Sebnem Kalemli-Ozcan Mehmet Fatih Ulu, 2017, “International Spillovers and Local Credit Cycles," NBER Working Paper 23149, March.

Basu, Kaushik, and Aristomene Varoudakis, Policy RWP 6469, World Bank, 2013, "How to Move the Exchange Rate If You Must: The Diverse Practice of Foreign Exchange Intervention by Central Banks and a Proposal for Doing it Better" May.

Basu, Suman, Atish R. Ghosh, Jonathan Ostry, and Pablo Winant, 2016 "Managing Capital Outflows: The Role of Foreign Exchange Intervention," Annual Research Conference, International Monetary Fund, Nov.

Beine, Michel, Agnes Bénassy-Quéré, and Christelle Lecourt. 2002, "Central Bank Intervention and Foreign Exchange Rates: New Evidence from FIGARCH Estimation,". Journal of International Money and Finance 21, no. 1: $115-44$.

Bénassy-Quéré, Agnès. 1999. "Exchange Rate Regimes and Policies: An Empirical Analysis." In Exchange Rate Policies in Emerging Asian Countries. edited by Stefan Collignon, Jean Pisani-Ferry and Yung Chul Park. (London: Routledge): 40-64.

Bénassy-Quéré, Agnès, Benoit Coeuré, and Valérie Mignon, 2004, "On the Identification of de facto Currency Pegs," Journal of the Japanese and International Economies 20(1): 112-27.

Blanchard, Olivier, Gustavo Adler, and Irineu de Carvalho Filho, 2015, "Can Foreign Exchange Intervention Stem Exchange Rate Pressures from Global Capital Flow Shocks?" IMF Working Paper 15/159 (Washington: International Monetary Fund).

Blanchard, O., Jonathan Ostry, Atish R. Ghosh, and Marcos Chamon, 2016, "Are capital inflows expansionary or contractionary? Theory, policy implications, and some evidence" National Bureau of Economic Research WP 21619.

Broda, Christian, 2004, "Terms of Trade and Exchange Rate Regimes in Developing Countries," Journal of International Economics, 63(1), pp. 31-58.

Bubula, A. and I. Ötker-Robe, 2002, "The Evolution of Exchange Rate Regimes since 1990: Evidence from De Facto Policies?" IMF Working Paper 02/155 (Washington, DC: IMF).

Calvo, Guillermo, and Carmen Reinhart, 2002, “Fear of Floating,” Quarterly Journal of Economics, May.

Cerutti, Eugenio, Stijn Claessens, and Damien Puy, 2015, "Push Factors and Capital Flows to Emerging Markets: Why Knowing Your Lender Matters More Than Fundamentals," June, IMF Working Paper No. 15-127.

Cashin, Paul, Luis F. Céspedes, and Ratna Sahay, 2004, "Commodity Currencies and the Real Exchange Rate," Journal of Development Economics 75, no.1: 239-268. 
Céspedes, Luis Felipe, and Andrés Velasco, 2012,"Macroeconomic Performance during Commodity Price Booms and Busts," IMF Economic Review 60, no.4: 570-599.

Chari, Anusha, Karlye Dilts Stedman, and Christian Lundblad, 2016,. "Taper tantrums: QE, its aftermath and emerging market capital flows." University of North Carolina, Chapel Hill.

Chen, Yu-chin, and Kenneth Rogoff, 2003, "Commodity Currencies," Journal of International Economics 60, no.1: 133-160.

Council on Foreign Relations, 1999, Safeguarding Prosperity in a Global Financial System: The Future International Financial Architecture. Washington, DC: Institute for International Economics.

Crockett, Andrew. 1994. "Monetary Policy Implications of Increased Capital Flows. In Changing Capital Markets: Implications for Monetary Policy," symposium sponsored by Federal Reserve Bank of Kansas City, Jackson Hole, August 1993.

Daude, Christian, Eduardo Levy-Yeyati and Arne Nagengast. 2014. "On the Effectiveness of Exchange Rate Intervention in Emerging Markets." OECD Development Centre Working Paper No. 324.

Devereux, Michael, and Charles Engel, 2002, "Exchange Rate Pass-Through, Exchange Rate Volatility, and Exchange Rate Disconnect,". Journal of Monetary Economics 49, no. 5: 913-40.

Devereux, Michael, and James Yetman. 2014. “Capital Controls, Global Liquidity Traps and the International Policy Trilemma," The Scandinavian Journal of Economics 116 (1), pp.158-189.

Di Giovanni, Julian, and Jay Shambaugh, 2008, "The Impact of Foreign Interest Rates on the Economy: The Role of the Exchange Rate Regime," Journal of International Economics 74, pp. 341-361.

Disyatat, Piti, and Gabriele Galati, 2007, "The Effectiveness of Foreign Exchange Intervention in Emerging Market Countries: Evidence from the Czech Koruna,". Journal of International Money and Finance 26, no. 3: 383-402.

Dominguez, Kathryn. 2006. "When Do Central Bank Interventions Influence Intra-Daily and Longer-Term Exchange Rate Movements?" Journal of International Money and Finance 25: 1051-71.

Dominguez, Kathryn, Rasmus Fatum, and Pavel Vacek, 2013, "Do Sales of Foreign Exchange Reserves Lead to Currency Appreciation?" Journal of Money, Credit and Banking 45, no. 5: 867-90.

Dominguez, Kathryn, and Jeffrey Frankel, 1993a, "Does Foreign Exchange Intervention Matter? The Portfolio Effect," American Economic Review 83, no. 5: 1356-369.

Dominguez, Kathryn, and Jeffrey Frankel, 1993b, Does Foreign Exchange Intervention Work? Washington: Institute for International Economics.

Edison, Hali, 1993. "The Effectiveness of Central-Bank Intervention: A Survey of the Literature after 1982." Special Papers in International Economics No. 18 (Princeton University Press: Princeton, NJ).

Edwards, Sebastian. 2015. “Monetary Policy Independence under Flexible Exchange Rates: An Illusion?” The World Economy $\underline{38}$ (5). May, pp.773-787. NBER Working Paper 20893.

Edwards, Sebastian, and Eduardo Levy Yeyati, 2005, "Flexible Exchange Rates as Shock Absorbers," European Economic Review, Vol. 49, Issue 8, November, pp. 2079-005.

Eichengreen, Barry, 1994, International Monetary Arrangements for the 21st Century (Washington, DC: Brookings Institution).

Eichengreen, Barry, and Raul Razo-Garcia, 2013, "How reliable are de facto exchange rate regime classifications?." International Journal of Finance \& Economics 18.3, pp. 216-239.

Farhi, Emmanuel and Ivan Werning, 2014, "Dilemma not Trilemma? Capital Controls and Exchange Rates with Volatile Capital Flows," IMF Economic Review, 62 (4), pp. 569-605. NBER WP No. 19854. 
Fatum, Rasmus. 2015. "FX Intervention When Interest Rates Are Zero: Does the Portfolio Balance Channel Matter after All?" Journal of International Money and Finance, 57(C), 185-199.

Fatum, Rasmus and Michael M. Hutchison. 2003. "Is Sterilized FX Intervention Effective after All? An Event Study Approach." Economic Journal, 113(487), 390-411.

Fatum, Rasmus and Michael M. Hutchison. 2010. "Evaluating FX Market Intervention: Selfselection, Counterfactuals and Average Treatment Effects." Journal of International Money and Finance, 29(3), 570-584.

Fischer, Stanley, 2001, “Exchange Rate Regimes: Is the Bipolar View Correct?” Journal of Economic Perspectives 15(2): 3-24.

Flood, Robert, and Andrew Rose, 1999, "Understanding exchange rate volatility without the contrivance of macroeconomics." The Economic Journal 109, no. 459, Nov: 660-672.

Forbes, Kristin, and Francis Warnock, 2012, “Capital Flow Waves: Surges Stops, Flight, and Retrenchment," Journal of International Economics, 2012, 88 (2), pp. 235-251.

Frankel, Jeffrey, 2003, "Experience of and Lessons from Exchange Rate Regimes in Emerging Economies," Monetary and Financial Cooperation in East Asia, Asian Development Bank (Macmillan).

Frankel, Jeffrey, 2009, "New Estimation of China's Exchange Rate Regime" in Pacific Economic Review, vol. 13, no. 3, pp. 346360.

Frankel, Jeffrey, 2016, "The Plaza Accord, 30 Years Later," in Currency Policy Then and Now: 30th Anniversary of the Plaza Accord, edited by C.F. Bergsten and Russell Green (Peterson Institute for International Economics: Washington DC).

Frankel, Jeffrey, 2017, "The Currency-Plus-Commodity Basket: A Proposal for Exchange Rates in Oil-Exporting Countries to Accommodate Trade Shocks Automatically," forthcoming, Macroeconomic Institutions and Management in Resource-Rich Arab Economies (Oxford University Press). CID WP no.333, Harvard University, March.

Frankel, Jeffrey. Eduardo Fajnzylber, Sergio Schmukler, and Luis Servén, 2001, "Verifying exchange rate regimes," Journal of Development Economics 66, no. 2, Dec., pp. 351-386.

Frankel, Jeffrey, Sergio Schmukler and Luis Servén, 2004, "Global Transmission of Interest Rates: Monetary Independence and the Currency Regime," Journal of International Money and Finance, 23, no. 5, September, 701-734.

Frankel, Jeffrey, and Shang-Jin Wei. 1994. "Yen Bloc or Dollar Bloc? Exchange Rate Policies of the East Asian Economies," In Macroeconomic Linkages: Savings, Exchange Rates, and Capital Flows, NBER - East Asia Seminar on Economics, Vol. 3, Takatoshi Ito and Anne Krueger, eds. (University of Chicago Press).

Frankel, Jeffrey, and Shang-Jin Wei, 2008, "Estimation of De Facto Exchange Rate Regimes: Synthesis of the Techniques for Inferring Flexibility and Basket Weights," IMF Staff Papers.

Frankel, Jeffrey, and Daniel Xie, 2010, "Estimation of De Facto Flexibility Parameter and Basket Weights in Evolving Exchange Rate Regimes," American Economic Review 100, May.

Frankel, Jeffrey, and Danxia Xie, 2017, "Estimating Exchange Rate Regimes with Sequential Nonlinear and Non-constant Inferences," in progress.

Fratzscher, Marcel, 2012, "Capital Flows, Push versus Pull Factors and the Global Financial Crisis," Journal of International Economics 88, pp.341-356. NBER Working Paper No. 17357.

Fratzscher, Marcel, Oliver Gloede, Lukas Menkhoff, Lucio Sarno, and Tobias Stöhr, 2016, "When is Foreign Exchange Intervention Effective? Evidence from 33 Countries." Discussion Papers of DIW Berlin 1518, DIW Berlin, German Institute for Economic Research, Novembe. Available at SSRN: https://ssrn.com/abstract=2686434 .

Friedman, Milton, 1953, "The Case for Flexible Exchange Rates," in Essays in Positive Economics. 
Frömmel, Michael, and Murat Midiliç, 2016, “"Daily Currency Interventions in Emerging Markets: Incorporating Reserve Accumulation." Proceedings of $25^{\text {th }}$ International Academic Conference, OECD Headquarters. No. 4106590, International Institute of Social and Economic Sciences.

Ghosh, Atish, Anne-Marie Gulde, and Holger Wolf. 2000. “Currency Boards: More than a Quick Fix?” Economic Policy, 31 (October):270-335.

Ghosh, Atish R., Jonathan Ostry, and Mahvash Qureshi, 2015, "Exchange rate management and crisis susceptibility: A reassessment." IMF Economic Review 63.1, May, pp. 238-276.

Girton, Lance and Don Roper. 1977. “A Monetary Model of Exchange Market Pressure Applied to the Postwar Canadian Experience." American Economic Review 67(4): 537-48.

Han, Xuewei, and Shang-Jin Wei, 2017, "International Transmissions of Monetary Shocks Between a Trilemma and a Dilemma," revised, May. NBER Working Paper No. 22812.

Humpage, Owen F. 1999. "US Intervention: Assessing the Probability of Success." Journal of Money, Credit and Banking, 31(4), 732-747.

Ilzetzki, Ethan, Carmen Reinhart, Kenneth Rogoff, 2017, “Exchange Arrangements Entering the 21st Century: Which Anchor Will Hold?" NBER WP No. 23134, Feb.

Ito, Takatoshi. 2001. "Discussion of the Case for a Basket, Band and Crawl (BBC) Regime for East Asia," Future Directions for Monetary Policies in East Asia, edited by David Gruen and John Simon (Sydney: Reserve Bank of Australia).

Ito, Takatoshi. 2003. "Is Foreign Exchange Intervention Effective: The Japanese Experience in the 1990s," in Paul Mizen (ed.) Monetary History, Exchange Rates and Financial Markets, Essays in Honour of Charles Goodhart, Volume 2. (Cheltenham U.K.: Edward Elgar Publishers).

Jeanne, Olivier and Romain Rancière, 2011, "The Optimal Level of International Reserves for Emerging Market Countries: A New Formula and Some Applications." Economic Journal, 121(555), 905-30.

Kaminsky, Graciela L., Carmen M. Reinhart, and Carlos A. Végh, 2005, "When It Rains It Pours: Procyclical Capital Flows and Macroeconomic Policies," NBER Macroeconomics Annual 2004, Volume 19 (MIT Press): 11-82.

Kearns, Jonathan and Roberto Rigobon, 2005, "Identifying the Efficacy of Central Bank Interventions: Evidence from Australia and Japan." Journal of International Economics, 66(1), 31-48.

Klein, Michael, and Nancy Marion. 1997. "Explaining the Duration of Exchange-Rate Pegs," Journal of Development Economics 54(2):387-404.

Klein, Michael, and Jay Shambaugh, 2012, Exchange rate regimes in the modern era. (MIT Press: Cambridge).

Klein, Michael and Jay Shambaugh, 2015. "Rounding the Corners of the Policy Trilemma: Sources of monetary policy autonomy," Feb. NBER WP 19461.

Krugman, Paul, 1991, “Target Zones and Exchange Rate Dynamics,” uarterly Journal of Economics, 106: 669-682.

Larrain, Felipe, and Andres Velasco. 2001. Exchange Rate Policy in Emerging Markets: The Case for Floating. Studies in International Economics no. 224 (Princeton NJ: Princeton University Press).

Levy Yeyati, Eduardo, and Federico Sturzenegger, 2001, "Exchange Rate Regimes and Economic Performance," IMF Staff Papers (February).

Levy-Yeyati, Eduardo, and Federico Sturzenegger, 2003, "To Float or to Trail: Evidence on the Impact of Exchange Rate Regimes on Growth," American Economic Review, 93(4), Sept. 1173-1193. 
Levy-Yeyati, E. and F. Sturzenegger, 2005, “Classifying Exchange Rate Regimes: Deeds vs. Words," European Economic Review, Vol. 49, No. 6, pp. 1603-1635.

Magud, Nicolas E., Carmen M. Reinhart, and Esteban R. Vesperoni. 2014, "Capital inflows, exchange rate flexibility and credit booms." Review of Development Economics 18.3: 415-430.

Meltzer, Alan. 2000. Report of the International Financial Institution Advisory Commission. Submitted to the US Congress and US Department of the Treasury, March 8.

Menkhoff, Lukas, 2010, "High-Frequency Analysis of FX Interventions: What Do We Learn?" Journal of Economic Surveys, 24(1),pp. 85-112.

Menkhoff, Lukas, 2013, “Foreign Exchange Intervention in Emerging Markets: A Survey of Empirical Studies," World Economy 36, no. 9: 1187-208.

Milesi-Ferretti, Gian-Maria, and Cédric Tille, 2011,. "The great retrenchment: international capital flows during the global financial crisis." Economic Policy 26.66 (2011): 289-346.

Miranda-Agrippino, Silvia, and Hélène Rey, 2015, "World Asset Markets and the Global Financial Cycle." National Bureau of Economic Research WP No. 21722.

Mohanty, MS, 2013, "Market volatility and foreign exchange intervention in EMEs: what has changed? An overview," in BIS papers vol. 73, (Bank for International Settlements: Basel), pp 01-10.

Mussa, Michael. 1981. The Role of Official Intervention. Group of Thirty Occasional Paper No. 6.

Mussa, Michael, 1986, "Nominal exchange rate regimes and the behavior of real exchange rates: Evidence and implications," Carnegie-Rochester Conference Series on Public Policy no. 25, pp. 117-214.

Obstfeld, Maurice, and Kenneth Rogoff. 1995. "The Mirage of Fixed Exchange Rates." Journal of Economic Perspectives 9 , no.4 (Fall):73-96.

Obstfeld, Maurice, 1990, "The Effectiveness of Foreign-Exchange Intervention: Recent Experience," International Policy Coordination and Exchange Rate Fluctuations, J. Frenkel, M. Goldstein, and W. Branson, eds.. (Chicago: Univ. of Chicago Press).

Obstfeld, Maurice, 1997, "Destabilizing effects of exchange-rate escape clauses," Journal of International Economics 43.1: 6177.

Obstfeld, Maurice, 2015, "Trilemmas and Tradeoffs: Living with Financial Globalization," in Global Liquidity, Spillovers to Emerging Markets and Policy Responses, eds. Claudio Raddatz, Diego Saravia and Jaume Ventura, pp. 13-78. (Santiago, Chile: Central Bank of Chile).

Obstfeld, Maurice, Jay Shambaugh, and Alan M. Taylor. 2005, "The trilemma in history: tradeoffs among exchange rates, monetary policies, and capital mobility." Review of Economics and Statistics 87, 3: pp.423-438.

Ogawa, Eiji. 2006. "The Chinese Yuan after the Chinese Exchange Rate System Reform," China and World Economy, 14(6), Nov.Dec.: 39-57.

Rafiq, M. Sohrab, 2011, "Sources of economic fluctuations in oil-exporting economies: implications for choice of exchange rate regimes," International Journal of Economics and Finance vol. 16 (1), Jan.: 70-91

Reinhart, Carmen, 2000, "The Mirage of Floating Exchange Rates," American Economic Review 90 (2), pp.65-70.

Reinhart, Carmen, and Vincent Reinhart, 2009, “Capital Flow Bonanzas: An Encompassing View of the Past and Present," in J.Frankel and C.Pissarides, eds., NBER International Seminar in Macroeconomics 2008 (Chicago: University of Chicago Press).

Reinhart, Carmen, and Kenneth Rogoff, 2004, "The Modern History of Exchange Rate Arrangements: A Reinterpretation." Quarterly Journal of Economics 119(1), February, pp. 1-48. 
Rey, Hélène. 2014. “Dilemma Not Trilemma: The Global Financial Cycle and Monetary Policy Independence," in Jackson Hole Economic Symposium 2013 (Federal Reserve Bank of Kansas City). National Bureau of Economic Research WP No. 21162, 2015.

Rodrik, Dani, 2006, "The social cost of foreign exchange reserves." International Economic Journal 20.3 , pp. 253-266.

Rose, Andrew, 2011, "Exchange Rate Regimes in the Modern Era: Fixed, Floating, and Flaky,"

J. Ec. Literature, Vol. 49, No. 3, Sept., pp. 652-672.

Sarno, Lucio, and Mark P. Taylor, 2001, "Official Intervention in the FX Markets: Is It Effective and, If So, How Does It Work?" Journal of Economic Literature, 34(3), 839-868.

Subramanian, Arvind, 2011a, "Renminbi Rules: The Conditional Imminence of the Reserve Currency Transition." Working Paper Series No. 11-14 (Washington, D.C.: Peterson Institute for International Economics, September).

Subramanian, Arvind, 2011b, Eclipse: Living in the Shadow of China's Economic Dominance (Washington, DC: Peterson Institute for International Economics).

Summers, Lawrence. 1999, "Building an International Financial Architecture for the $21^{\text {st }}$ Century." Cato Journal, 18(3):321-330.

Tavlas, George, Dellas, Harris, and Stockman, Alan, 2008. "The Classification and Performance of Alternative Exchange-Rate Systems," European Economic Review, 52(6): 941-63, August.

Taylor, Alan M., 2002, “A Century of Purchasing Power Parity." Review of Economics and Statistics 84, February, pp.: 139-50.

Truman , Edwin, 2003, "The Limits of Exchange Market Intervention,: in Dollar Overvaluation and the World Economy, C. Fred Bergsten and John Williamson, eds., 247-65 (Washington: Peterson Institute for International Economics).

Williamson, John, 2001. "The Case for a Basket, Band and Crawl (BBC) Regime for East Asia," In Future Directions for Monetary Policies in East Asia, edited by David Gruen and John Simon. Sydney: Reserve Bank of Australia: 97-111. 


\section{Appendix Tables 1 \& 2: Estimation of Weights and Flexibility Parameter}

Appendix Table 1. Identifying Break Points in Thailand's Exchange Rate Regime (M1:1999-M5:2009)

\begin{tabular}{lcccc}
\hline \multirow{2}{*}{ VARIABLES } & $(1)$ & $(2)$ & $(3)$ & $(4)$ \\
& $1 / 21 / 1999-$ & $8 / 12 / 2001-$ & $9 / 16 / 2006-$ & $4 / 1 / 2007-$ \\
& $8 / 5 / 2001$ & $9 / 9 / 2006$ & $3 / 25 / 2007$ & $5 / 6 / 2009$ \\
\hline US dollar & $0.62^{* * *}$ & $0.61^{* * *}$ & $0.80^{* * *}$ & $0.70^{* * *}$ \\
& $(0.09)$ & $(0.04)$ & $(0.28)$ & $(0.05)$ \\
Euro & $0.26^{* * *}$ & $0.17^{* * *}$ & -0.08 & $0.19^{* * *}$ \\
& $(0.08)$ & $(0.06)$ & $(0.59)$ & $(0.04)$ \\
Jpn yen & $0.15^{* * *}$ & $0.25^{* * *}$ & 0.16 & 0.04 \\
& $(0.04)$ & $(0.03)$ & $(0.30)$ & $(0.03)$ \\
$\Delta$ EMP & $0.20^{* * *}$ & $0.06^{* * *}$ & $0.50 * * *$ & $0.03^{* *}$ \\
& $(0.05)$ & $(0.02)$ & $(0.17)$ & $(0.01)$ \\
Constant & $-0.00^{* *}$ & 0.00 & -0.01 & -0.00 \\
& $(0.00)$ & $(0.00)$ & $(0.00)$ & $(0.00)$ \\
Observations & 129 & 257 & 27 & 108 \\
$\mathrm{R}^{2}$ & 0.66 & 0.76 & 0.64 & 0.90 \\
GB£ & -0.02 & -0.04 & 0.12 & 0.07 \\
\hline
\end{tabular}

Appendix Table 2. Identifying Break Points in India's Exchange Rate Regime (M1:2000-M5:2009)

\begin{tabular}{lcccccc}
\hline \multirow{2}{*}{ VARIABLES } & $(1)$ & $(2)$ & $(3)$ & $(4)$ & $(5)$ & $(6)$ \\
& $1 / 14 / 2000-$ & $11 / 3 / 2000-$ & $6 / 24 / 2001-$ & $1 / 14 / 2002-$ & $9 / 30 / 2003-$ & $3 / 4 / 2007-$ \\
& $10 / 27 / 2000$ & $6 / 17 / 2001$ & $12 / 31 / 2001$ & $9 / 23 / 2003$ & $2 / 25 / 2007$ & $5 / 6 / 2009$ \\
\hline US dollar & $0.77^{* * *}$ & $0.92^{* * *}$ & $0.66^{* * *}$ & $0.91^{* * *}$ & $0.72 * * *$ & $0.59^{* * *}$ \\
& $(0.06)$ & $(0.04)$ & $(0.08)$ & $(0.04)$ & $(0.06)$ & $(0.10)$ \\
Euro & $0.12^{* * *}$ & $0.10^{* * *}$ & $0.23^{* * *}$ & 0.03 & 0.06 & $0.32^{* * *}$ \\
& $(0.03)$ & $(0.03)$ & $(0.07)$ & $(0.03)$ & $(0.05)$ & $(0.07)$ \\
Jpn yen & $0.09 * * *$ & $0.04^{*}$ & 0.05 & 0.03 & $0.24 * * *$ & 0.02 \\
& $(0.02)$ & $(0.02)$ & $(0.05)$ & $(0.02)$ & $(0.06)$ & $(0.07)$ \\
$\Delta E M P$ & $0.44^{* * *}$ & 0.04 & $0.46 * * *$ & 0.06 & $0.15 * * *$ & $0.37^{* * *}$ \\
& $(0.06)$ & $(0.04)$ & $(0.10)$ & $(0.04)$ & $(0.05)$ & $(0.07)$ \\
Observations & 42 & 32 & 28 & 88 & 172 & 109 \\
$\mathrm{R}^{2}$ & 0.98 & 0.98 & 0.98 & 0.98 & 0.86 & 0.78 \\
GBE & 0.02 & -0.06 & 0.06 & 0.03 & -0.01 & 0.08 \\
\hline
\end{tabular}

Notes: $\triangle E M P$ is the exchange rate market pressure variable, which is defined as the percentage increase in the value of the local currency plus the increase in reserves (scaled by the monetary base)

$$
\begin{aligned}
& \Delta E M P_{t}=\Delta \log H_{t}+\frac{\left[\operatorname{Re} \text { serve }_{t}-\operatorname{Re} \text { serve }_{t-1}\right]}{M B_{t-1}} \text { All data are weekly. } \\
& * * * \mathrm{p}<0.01, * * \mathrm{p}<0.05, * \mathrm{p}<0.1 \text { (Robust standard errors in parentheses.) }
\end{aligned}
$$

Source: Frankel and Xie (2011). 


\section{Appendix Tables A and B: Effect of Shocks on Real Exchange Rates}

Appendix Tables A: Effect of Shocks on Real Exchange Rates among Asia Non-Commodity-Exporters A1) OLS: Log of REER on Log of VIX and lagged REER

\begin{tabular}{lllllllll}
\hline \multirow{2}{*}{ VARIABLES } & $\mathbf{( 1 )}$ & $\mathbf{( 2 )}$ & $\mathbf{( 3 )}$ & $\mathbf{( 4 )}$ & $\mathbf{( 5 )}$ & $\mathbf{( 6 )}$ & $\mathbf{( 7 )}$ & $\mathbf{( 8 )}$ \\
& HKG & India & Korea, R & Malaysia & Philippines & Singapore & Thailand & Turkey \\
\hline & & & & & & & & \\
Log of VIX & 0.002 & $-0.006^{*}$ & $-0.047^{* * *}$ & $-0.009^{*}$ & $-0.011^{* * *}$ & $-0.005^{* * *}$ & $-0.011^{* * *}$ & $-0.019^{* * *}$ \\
& $(0.004)$ & $(0.003)$ & $(0.009)$ & $(0.005)$ & $(0.003)$ & $(0.002)$ & $(0.003)$ & $(0.006)$ \\
REER Lag & $0.993^{* * *}$ & $0.987^{* * *}$ & $0.874^{* * *}$ & $0.935^{* * *}$ & $0.996^{* * *}$ & $0.997^{* * *}$ & $0.970^{* * *}$ & $0.955^{* * *}$ \\
& $(0.008)$ & $(0.012)$ & $(0.027)$ & $(0.028)$ & $(0.007)$ & $(0.005)$ & $(0.024)$ & $(0.016)$ \\
Constant & 0.027 & 0.080 & $0.703^{* * *}$ & $0.326^{* *}$ & 0.053 & 0.028 & 0.171 & $0.254^{* * *}$ \\
& $(0.035)$ & $(0.056)$ & $(0.141)$ & $(0.126)$ & $(0.033)$ & $(0.026)$ & $(0.112)$ & $(0.077)$ \\
\hline Observations & 227 & 227 & 227 & 227 & 227 & 227 & 227 & 227 \\
R-squared & 0.990 & 0.968 & 0.928 & 0.904 & 0.986 & 0.992 & 0.954 & 0.956 \\
\hline
\end{tabular}

\section{A2) IV: Log of REER on $\triangle$ Res/GDP and lagged REER}

Instrument: log of VIX

\begin{tabular}{|c|c|c|c|c|c|c|c|c|}
\hline & (1) & (2) & (3) & (4) & (5) & (6) & (7) & (8) \\
\hline VARIABLES & HKG & India & Korea, R. & Malaysia & Philippines & Singapore & Thailand & Turkey \\
\hline \multirow[t]{2}{*}{$\triangle \operatorname{Res} / G D P$} & 0.074 & 0.396 & $1.754^{* * *}$ & 0.291 & 11.118 & 0.220 & -6.360 & $1.785^{* * *}$ \\
\hline & $(0.139)$ & (0.419) & (0.411) & $(0.209)$ & (43.304) & (0.193) & (26.523) & (0.653) \\
\hline \multirow[t]{2}{*}{ REER Lag } & $0.997 * * *$ & $0.993 * * *$ & $1.039 * * *$ & $0.979 * * *$ & $0.962 * * *$ & $1.029 * * *$ & 0.748 & $0.967^{* * *}$ \\
\hline & (0.008) & $(0.020)$ & (0.029) & $(0.049)$ & $(0.162)$ & $(0.024)$ & (0.946) & $(0.020)$ \\
\hline \multirow[t]{2}{*}{ Constant } & 0.011 & 0.030 & -0.188 & 0.093 & 0.098 & -0.137 & 1.207 & 0.139 \\
\hline & $(0.042)$ & $(0.092)$ & $(0.131)$ & $(0.227)$ & $(0.493)$ & $(0.116)$ & (4.551) & $(0.090)$ \\
\hline Observations & 227 & 144 & 227 & 227 & 227 & 219 & 225 & 225 \\
\hline R-squared & 0.987 & 0.960 & 0.912 & 0.882 & & 0.975 & & 0.937 \\
\hline
\end{tabular}

Robust standard errors in parentheses; *** $p<0.01, * * p<0.05, * p<0.1$ 


\section{Appendix Tables B: Effect of Shocks on Real Exchange Rates Among Commodity-Exporters}

B1) OLS: Log of REER on a country-specific commodity price index and lagged REER

\begin{tabular}{|c|c|c|c|c|c|c|c|c|c|c|c|}
\hline & (1) & (2) & (3) & (4) & (5) & (6) & (7) & (8) & (9) & (10) & (11) \\
\hline VARIABLES & Austral. & New Zea. & S. Africa & Brazil & Chile & Colombia & Ecuador & Peru & UAE & Indonesia & Papua NG \\
\hline Commodity & $0.038 * * *$ & $0.086 * *$ & 0.000 & $0.144 * * *$ & $0.012^{*}$ & 0.011 & 0.010 & $0.008 * *$ & -0.030 & $0.091 * * *$ & $0.025^{* * *}$ \\
\hline Price Indices & $(0.015)$ & $(0.042)$ & $(0.010)$ & $(0.052)$ & $(0.006)$ & $(0.008)$ & $(0.010)$ & $(0.004)$ & $(0.020)$ & $(0.033)$ & $(0.006)$ \\
\hline \multirow[t]{2}{*}{ REER Lag } & $0.944^{* * *}$ & $0.955^{* * *}$ & $0.970 * * *$ & $0.952 * * *$ & $0.960 * * *$ & $0.981^{* * *}$ & $0.965^{* * *}$ & $0.970 * * *$ & $0.942^{* * *}$ & $0.890 * * *$ & $0.963 * * *$ \\
\hline & (0.019) & $(0.022)$ & $(0.021)$ & $(0.017)$ & $(0.014)$ & $(0.016)$ & $(0.036)$ & $(0.013)$ & $(0.049)$ & $(0.041)$ & $(0.013)$ \\
\hline \multirow[t]{2}{*}{ Constant } & $0.269 * * *$ & $0.244 * *$ & 0.138 & $0.229 * * *$ & $0.170 * * *$ & 0.091 & 0.170 & $0.138^{* *}$ & 0.273 & $0.535^{* * *}$ & $0.187^{* * *}$ \\
\hline & $(0.092)$ & $(0.114)$ & $(0.095)$ & $(0.079)$ & $(0.064)$ & $(0.077)$ & $(0.170)$ & $(0.059)$ & $(0.233)$ & $(0.197)$ & $(0.062)$ \\
\hline Observations & 226 & 226 & 227 & 227 & 227 & 227 & 227 & 227 & 107 & 227 & 227 \\
\hline R-squared & 0.983 & 0.975 & 0.928 & 0.973 & 0.949 & 0.963 & 0.935 & 0.965 & 0.936 & 0.908 & 0.973 \\
\hline
\end{tabular}

Robust standard errors in parentheses; ${ }^{* *} p<0.01, * * p<0.05, * p<0.1$

\begin{tabular}{|c|c|c|c|c|c|c|c|c|c|c|}
\hline & (12) & (13) & (14) & (15) & (16) & (17) & (18) & (19) & (20) & $(21)$ \\
\hline VARIABLES & Azerbaij. & Bahrain & Brunei & Canada & Kazakhstan & Kuwait & Qatar & Russia & Saudi Arabia & Mongolia \\
\hline Commodity & $0.011^{* * *}$ & -0.002 & $0.004^{* * *}$ & $0.013^{* * *}$ & $0.014^{* * *}$ & $0.003^{*}$ & 0.002 & $0.033^{*} *$ & $0.004 * *$ & $0.044^{* * *}$ \\
\hline Price Indices & (0.004) & $(0.004)$ & (0.001) & (0.004) & (0.005) & $(0.002)$ & $(0.003)$ & $(0.016)$ & $(0.002)$ & $(0.015)$ \\
\hline \multirow[t]{2}{*}{ REER Lag } & $0.979 * * *$ & $0.979 * * *$ & $0.980 * * *$ & $0.939 * * *$ & $0.958 * * *$ & $0.996 * * *$ & $1.001 * * *$ & $0.926 * * *$ & $1.015^{* * *}$ & $0.946 * * *$ \\
\hline & (0.010) & $(0.021)$ & $(0.008)$ & (0.019) & (0.018) & (0.010) & $(0.013)$ & $(0.028)$ & (0.010) & $(0.025)$ \\
\hline \multirow[t]{2}{*}{ Constant } & $0.105^{* *}$ & 0.100 & $0.094 * *$ & $0.279 * * *$ & $0.198 * *$ & 0.022 & -0.003 & $0.349 * * *$ & -0.069 & $0.264 * *$ \\
\hline & $(0.050)$ & $(0.095)$ & $(0.039)$ & $(0.086)$ & $(0.084)$ & $(0.049)$ & (0.059) & $(0.130)$ & $(0.048)$ & $(0.118)$ \\
\hline Observations & 227 & 227 & 227 & 227 & 227 & 227 & 156 & 227 & 227 & 227 \\
\hline R-squared & 0.988 & 0.979 & 0.982 & 0.984 & 0.965 & 0.976 & 0.978 & 0.974 & 0.980 & 0.968 \\
\hline
\end{tabular}

Robust standard errors in parentheses; $* * * p<0.01, * * p<0.05, * p<0.1$ 
B2) OLS: Log of REER on a country-specific commodity price index, log of VIX and lagged REER

\begin{tabular}{|c|c|c|c|c|c|c|c|c|c|c|c|c|c|}
\hline & (1) & (2) & (3) & (4) & (5) & \multicolumn{2}{|l|}{ (6) } & \multicolumn{2}{|l|}{ (7) } & (8) & (9) & (10) & (11) \\
\hline VARIABLES & Austral & New Zea. & S. Africa & Brazil & Chile & \multicolumn{2}{|c|}{ Colombia } & \multicolumn{2}{|c|}{ Ecuador } & Peru & UAE & Indonesia & Papua NG \\
\hline Commodity & $0.039 * * *$ & $0.140 * * *$ & -0.003 & $0.100^{*}$ & 0.007 & \multicolumn{2}{|c|}{0.005} & \multicolumn{2}{|c|}{0.012} & $0.010 * * *$ & -0.023 & $0.087^{* * *}$ & $0.027^{* * *}$ \\
\hline Price Indices & $(0.014)$ & $(0.043)$ & $(0.011)$ & $(0.054)$ & $(0.007)$ & \multicolumn{2}{|c|}{ (0.009) } & \multicolumn{2}{|c|}{$(0.010)$} & $(0.004)$ & (0.019) & $(0.033)$ & $(0.006)$ \\
\hline \multirow[t]{2}{*}{ Log of VIX } & -0.012 & $-0.021 * * *$ & -0.008 & $-0.021 * *$ & -0.008 & \multicolumn{2}{|c|}{$-0.013^{*}$} & \multicolumn{2}{|c|}{0.005} & 0.005 & 0.006 & -0.006 & 0.009 \\
\hline & $(0.008)$ & $(0.005)$ & $(0.008)$ & $(0.009)$ & $(0.006)$ & \multicolumn{2}{|c|}{$(0.007)$} & \multicolumn{2}{|c|}{$(0.005)$} & $(0.003)$ & $(0.006)$ & $(0.009)$ & $(0.007)$ \\
\hline \multirow[t]{2}{*}{ REER Lag } & $0.934 * * *$ & $0.905^{* * *}$ & $0.966 * * *$ & $0.959 * * *$ & $0.964 * * *$ & \multicolumn{2}{|c|}{$0.985^{* * *}$} & \multicolumn{2}{|c|}{$0.967 * * *$} & $0.969 * * *$ & $0.951 * * *$ & $0.890 * * *$ & $0.963 * * *$ \\
\hline & $(0.018)$ & $(0.026)$ & $(0.020)$ & $(0.017)$ & $(0.015)$ & $(0.01 \epsilon$ & & $(0.03)$ & & $(0.013)$ & $(0.048)$ & $(0.041)$ & $(0.013)$ \\
\hline Constant & $0.352 * * *$ & $0.554 * * *$ & $0.180^{*}$ & $0.253 * * *$ & $0.181 * * *$ & 0.110 & & 0.149 & & $0.131 * *$ & 0.214 & $0.551^{* * *}$ & $0.158 * *$ \\
\hline & $(0.090)$ & $(0.143)$ & (0.096) & $(0.077)$ & $(0.063)$ & $(0.07)$ & & $(0.17$ & & $(0.060)$ & $(0.231)$ & (0.199) & $(0.066)$ \\
\hline Observations & 226 & 226 & 227 & 227 & 227 & 227 & & 227 & & 227 & 107 & 227 & 227 \\
\hline R-squared & 0.984 & 0.977 & 0.929 & 0.974 & 0.950 & 0.964 & & 0.935 & & 0.966 & 0.937 & 0.908 & 0.973 \\
\hline & $(12)$ & (13) & (14) & (15) & $(16)$ & & (17) & & (18 & & (19) & $(20)$ & (21) \\
\hline VARIABLES & Azerbaij & Bahrain & Brunei & Canada & Kazakhst & $\tan$ & Kuwa & & Qa & & Russia & Saudi Arabia & Mongolia \\
\hline Commodity & & & & & & & & & & & & & \\
\hline Price Indices & $0.014^{* * *}$ & -0.002 & $0.004^{* * *}$ & $0.011 * * *$ & $0.014 * *$ & & 0.004 & & 0.0 & & $0.029 * *$ & $0.005 * *$ & $0.045^{* * *}$ \\
\hline & $(0.005)$ & $(0.004)$ & $(0.001)$ & $(0.004)$ & $(0.005)$ & & $(0.00$ & & 10.0 & 03) & (0.014) & $(0.002)$ & $(0.017)$ \\
\hline Log of VIX & 0.007 & 0.003 & 0.001 & $-0.009 *$ & -0.002 & & 0.004 & & 0.0 & & -0.016 & 0.005 & 0.002 \\
\hline & $(0.007)$ & $(0.004)$ & $(0.002)$ & $(0.005)$ & $(0.008)$ & & 10.00 & & $(0.0$ & 06) & $(0.010)$ & $(0.004)$ & $(0.008)$ \\
\hline REER Lag & $0.976 * * *$ & $0.979 * * *$ & $0.980 * * *$ & $0.937 * * *$ & $0.959 * * *$ & & 0.994 & $* * *$ & 1.0 & $1 * * *$ & $0.928 * * *$ & $1.014 * * *$ & $0.945^{* * *}$ \\
\hline & $(0.012)$ & $(0.020)$ & $(0.009)$ & $(0.019)$ & $(0.017)$ & & (0.01c & & $(0.0$ & 12) & $(0.026)$ & $(0.011)$ & $(0.025)$ \\
\hline Constant & $0.101^{* *}$ & 0.090 & $0.094 * *$ & $0.314^{* * *}$ & $0.201^{* *}$ & & 0.022 & & -0.0 & & $0.385 * * *$ & -0.076 & $0.261^{* *}$ \\
\hline & $(0.048)$ & $(0.092)$ & $(0.039)$ & $(0.088)$ & $(0.087)$ & & (0.04؟ & & $(0.0$ & 57) & $(0.141)$ & $(0.048)$ & $(0.117)$ \\
\hline Observations & 227 & 227 & 227 & 227 & 227 & & 227 & & 156 & & 227 & 227 & 227 \\
\hline R-squared & 0.988 & 0.980 & 0.982 & 0.985 & 0.965 & & 0.976 & & 0.9 & & 0.974 & 0.980 & 0.968 \\
\hline
\end{tabular}

Robust standard errors in parentheses; *** $p<0.01, * * p<0.05, * p<0.1$ 
B3) IV: Log of REER on $\triangle R e s / G D P$ and a time trend

Instruments: log of VIX and a country-specific commodity price index

\begin{tabular}{|c|c|c|c|c|c|c|c|}
\hline & (1) & (2) & (3) & (4) & (5) & (6) & (7) \\
\hline VARIABLES & S. Africa & Brazil & Chile & Colombia & Ecuador & Peru & Aze \\
\hline \multirow[t]{2}{*}{$\Delta R e s / G D P$} & -1.260 & $20.527 * * *$ & $14.315^{* *}$ & $23.670 * * *$ & 0.002 & $-0.807^{*}$ & 0.4 \\
\hline & (3.837) & $(6.402)$ & (5.900) & $(8.312)$ & $(0.006)$ & $(0.458)$ & (0. \\
\hline \multirow[t]{2}{*}{ Time trend } & $-0.005^{* * *}$ & $0.001^{* * *}$ & 0.000 & 0.000 & -0.005 & $0.001^{* * *}$ & 0.0 \\
\hline & $(0.000)$ & $(0.000)$ & $(0.000)$ & $(0.000)$ & $(0.012)$ & $(0.000)$ & (0. \\
\hline \multirow[t]{2}{*}{ Constant } & $5.484^{* * *}$ & $4.288^{* * *}$ & $4.559 * * *$ & $4.470 * * *$ & $5.009 * * *$ & $4.616^{* * *}$ & 4.0 \\
\hline & (0.093) & $(0.073)$ & $(0.046)$ & $(0.039)$ & $(0.774)$ & $(0.010)$ & (0. \\
\hline Observations & 70 & 227 & 227 & 227 & 130 & 227 & 18 \\
\hline R-squared & 0.747 & & & & & 0.207 & 0.7 \\
\hline \multicolumn{8}{|c|}{ Robust standard errors in parentheses; ${ }^{* * *} p<0.01,{ }^{* *} p<0.05, * p<0.1$} \\
\hline & (8) & (9) & (10) & (11) & (12) & (13) & \\
\hline VARIABLES & Bahrain & Brunei & Kazakhstan & Qatar & Russia & Saudi Arabia & \\
\hline \multirow[t]{2}{*}{$\Delta \operatorname{Res} / G D P$} & $-1.269 * *$ & 2.004 & $-2.562 * *$ & $-1.670 *$ & $3.071 * * *$ & $-1.396 * * *$ & \\
\hline & $(0.526)$ & $(2.074)$ & $(1.163)$ & $(0.897)$ & $(1.109)$ & $(0.181)$ & \\
\hline \multirow[t]{2}{*}{ Time trend } & $0.006 * * *$ & $0.001^{* * *}$ & $0.002 * * *$ & $0.002 * * *$ & $0.003 * * *$ & $0.001^{* * *}$ & \\
\hline & $(0.002)$ & $(0.000)$ & $(0.000)$ & $(0.001)$ & $(0.000)$ & $(0.000)$ & \\
\hline \multirow[t]{2}{*}{ Constant } & $3.370 * * *$ & $4.439 * * *$ & $4.343 * * *$ & $4.250 * * *$ & $4.045^{* * *}$ & $4.555^{* * *}$ & \\
\hline & $(0.386)$ & $(0.020)$ & $(0.026)$ & $(0.114)$ & $(0.042)$ & $(0.054)$ & \\
\hline Observations & 19 & 142 & 225 & 72 & 227 & 72 & \\
\hline R-squared & 0.338 & & 0.249 & & 0.390 & 0.735 & \\
\hline
\end{tabular}




\section{B4) IV: Log of REER on $\triangle R e s / M 1$ and a time trend}

Instruments: log of VIX and a price index

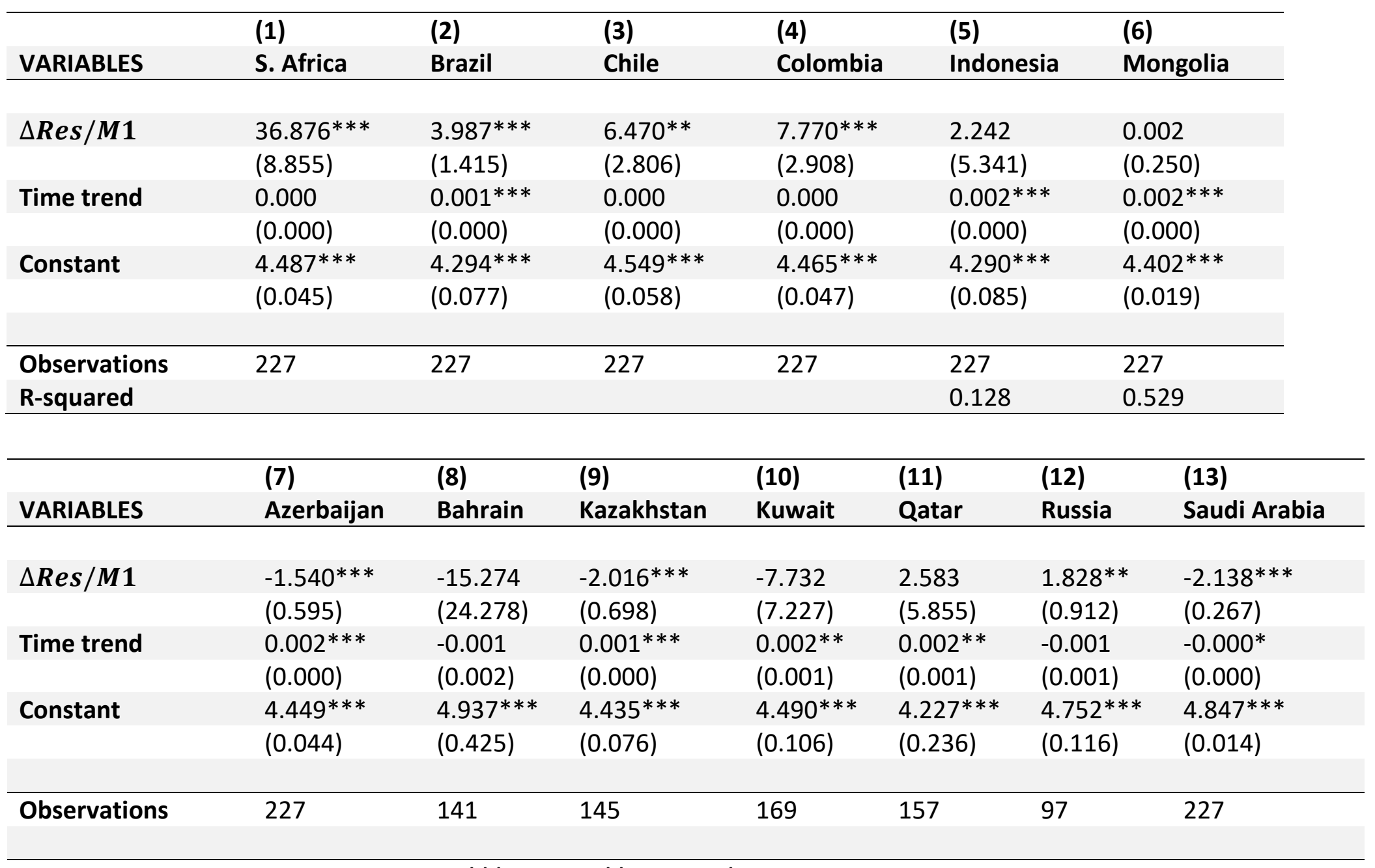

Robust standard errors in parentheses; ${ }^{* * *} p<0.01, * * p<0.05, * p<0.1$ 
B5) IV: Log of REER on $\triangle R e s / M B$ and a time trend

Instruments: log of VIX and a price index

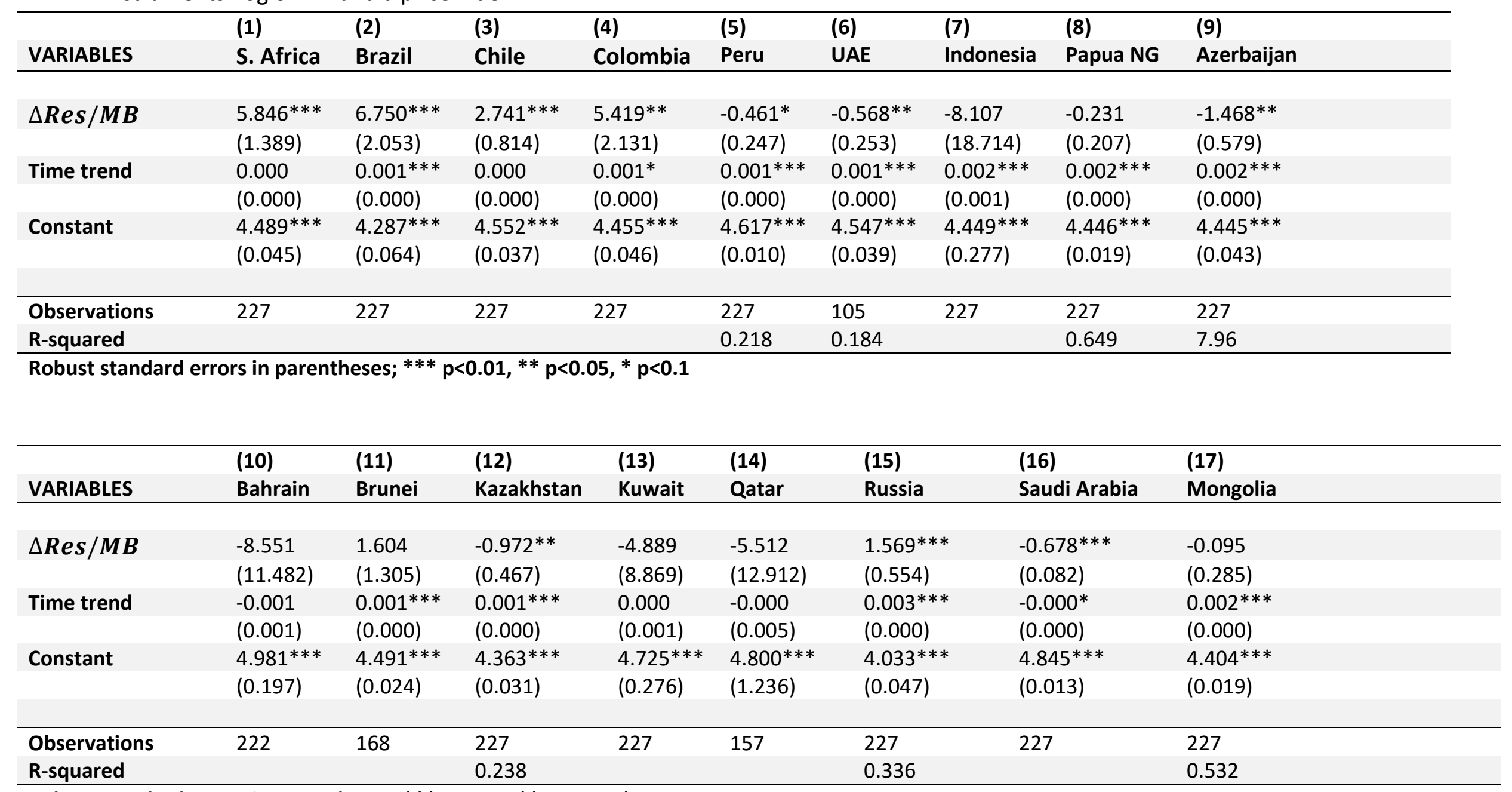

Robust standard errors in parentheses; ${ }^{* * *} p<0.01,{ }^{* *} p<0.05,{ }^{*} p<0.1$ 